NBER WORKING PAPER SERIES

THE SMOOT-HAWLEY TRADE WAR

Kris James Mitchener

Kirsten Wandschneider

Kevin Hjortshøj O'Rourke

Working Paper 28616

http://www.nber.org/papers/w28616

\author{
NATIONAL BUREAU OF ECONOMIC RESEARCH \\ 1050 Massachusetts Avenue \\ Cambridge, MA 02138 \\ March 2021
}

O'Rourke gratefully acknowledges the hospitality of Sciences Po as well as the financial support of the ERC, under the European Union's Seventh Framework Programme (FP7/2007-2013), ERC grant agreement 249546; the Oxford History Faculty's Sanderson Fund; the John Fell OUP Research Fund; and NYU Abu Dhabi. Alan Fernihough and Silvi Berger collected the monthly and quarterly trade data and we are extremely grateful to both as well as to Lorenz Reiter, Alexander Wulfers and Adrian Daues for outstanding research assistance. We thank Doug Irwin and Wolfgang Keller as well as seminar and conference participants at the 2021 ASSA Meetings, University of Vienna, and the Mountain West Economic History Conference for helpful comments and suggestions, and Thierry Mayer and Raymond Hicks, who were particularly generous in answering our queries and providing data. The views expressed herein are those of the authors and do not necessarily reflect the views of the National Bureau of Economic Research.

NBER working papers are circulated for discussion and comment purposes. They have not been peer-reviewed or been subject to the review by the NBER Board of Directors that accompanies official NBER publications.

(C) 2021 by Kris James Mitchener, Kirsten Wandschneider, and Kevin Hjortshøj O'Rourke. All rights reserved. Short sections of text, not to exceed two paragraphs, may be quoted without explicit permission provided that full credit, including $\odot$ notice, is given to the source. 
The Smoot-Hawley Trade War

Kris James Mitchener, Kirsten Wandschneider, and Kevin Hjortshøj O'Rourke

NBER Working Paper No. 28616

March 2021

JEL No. F13,F14,N70,N72

\begin{abstract}
$\underline{\text { ABSTRACT }}$
We document the outbreak of a trade war after the U.S. adopted the Smoot-Hawley tariff in June 1930. U.S. trade partners initially protested the possible implementation of the sweeping tariff legislation, with many eventually choosing to retaliate by increasing their tariffs on imports from the United States. Using a new quarterly dataset on bilateral trade for 99 countries during the interwar period, we show that U.S. exports to countries that protested fell by between 15 and 22 percent, while U.S. exports to retaliators fell by 28-33 percent. Furthermore, using a second new dataset on U.S. exports at the product-level, we find that the most important U.S. exports to retaliating markets were particularly affected, suggesting a possible mechanism whereby the U.S. was targeted despite countries' MFN obligations. The retaliators' welfare gains from trade fell by roughly $8-17 \%$.

Kris James Mitchener

Department of Economics

Leavey School of Business

Santa Clara University

Santa Clara, CA 95053

and NBER

kmitchener@scu.edu

Kirsten Wandschneider

Department of Business, Economics and Statistics

Department of Economic and Social History

University of Vienna

Oskar-Morgenstern-Platz 1

1090 Vienna

Vienna 1090

Austria

kirsten.wandschneider@univie.ac.at

Kevin Hjortshøj O'Rourke

NYU Abu Dhabi, Saadiyat Campus

Social Science (A5), 1193

P.O. Box 129188

Abu Dhabi

United Arab Emirates

and NBER

kevin.orourke@nyu.edu
\end{abstract}




\section{The Smoot-Hawley Trade War}

\section{Introduction}

"The ghost of Smoot-Hawley seems to haunt President Trump."1 As fears of a trade war between the U.S. and China grew after the U.S. presidential election of 2016, many commentators drew precisely this link between the events of 1930 and today. And the consensus was that the trade wars of the 1930s were an ominous portent of what might await the world if Donald Trump's protectionist impulses were not checked.

Empirical and theoretical interest in understanding the effects of trade wars has surged in response to the recent U.S.-China trade war. A fast-moving literature focuses on the effects of the tariff increases of 2018-19 on U.S. manufacturing employment, producer prices, and capital expenditure of firms as well as welfare losses in the form of higher prices and nearly complete pass through (Amiti, Redding and Weinstein, 2019; Amiti, Kong, and Weinstein, 2020; Flaen and Pierce, 2020; Fajgelbaum et. al., 2020). On the other hand, while economists have for decades used the tariff wars sparked by the Smoot-Hawley legislation of June 1930 as a cautionary tale of what can go wrong when protectionism gets out of hand, little quantitative work has been conducted on the Smoot-Hawley trade war. Even more surprisingly, perhaps, for non-specialists, the general conclusion of quantitative economic historians who have explored the effects of 1930s protectionism is that it had less of an impact than was traditionally thought. The basic point is straightforward: the collapse in GDP during the Great Depression was so large that, on its own, it can explain the bulk of the trade collapse of 1929-33: there is relatively little left over for a rise in trade costs to explain (Irwin, 1998a). Our paper aims to fill this gap in the literature: we estimate the quantitative impact of the Smoot-Hawley trade war on trade flows and conclude that it was big.

While there exists a large scholarly literature on the Smoot-Hawley tariff, only some of it is quantitative. ${ }^{2}$ Several papers ask what drove legislators to vote for or against Smoot-Hawley: was party affiliation the dominant factor (Pastor, 1980), or as argued by Eichengreen (1989), did

\footnotetext{
1 "The ghost of Smoot-Hawley seems to haunt Trump", Robert J. Samuelson, Washington Post, June 27, 2018. Available at (accessed March 11, 2019).

${ }^{2}$ For recent overviews, see Irwin (2011) and the discussion in Irwin (2017).
} 
economic interests play an important and independent role (Callahan et al., 1994, Cupitt and Elliott, 1994, Irwin and Kroszner, 1996)? This literature is not directly relevant to our paper. There have been some papers exploring the impact of tariffs and other trade barriers on the aggregate value and composition of trade during the 1930s (Crucini, 1994, Crucini and Kahn, 2003, Mann, 1987, Irwin, 1998a, 1998b, Madsen, 2001, James, 2001, de Bromhead et al., 2019), but while some of them look specifically at the impact of the Smoot-Hawley tariff, virtually none study the trade war that the tariff provoked. This paper aims to do just this.

We focus on the act of retaliation - when countries decide to raise trade barriers, not for domestic reasons, but primarily for the purpose of responding to other countries' actions. In particular, we ask two questions. First, what determined whether a country officially protested Smoot-Hawley, or went one step further and actually retaliated? And second, what was the impact of retaliation on trade flows?

Based on contemporary sources and government documents, we first identify country responses to Smoot-Hawley (whether they filed official protests with the U.S. government, retaliated by imposing tariffs, or simply did nothing). We analyze whether these responses are predicted by trade or political relationships with the U.S. Interestingly, we find that a country's response to Smoot-Hawley is not determined by a country's pre-1930 share of exports or bilateral trade balance with the United States. The main focus of the paper, however, is on the effects of the Smoot-Hawley trade war on bilateral imports. We estimate these using a structural gravity model, and a new, hand-collected quarterly dataset on bilateral trade for 99 countries during the interwar period. This is to our knowledge the first high-frequency bilateral dataset to have been constructed for this period. These new quarterly data allow for more precise identification of the timing of the response to Smoot-Hawley. In particular, we focus on the behavior of those countries that responded to Smoot-Hawley by either filing official protests against Smoot-Hawley and/or imposing retaliatory tariffs against the U.S. We employ gravity model estimates to compare these "responders" to U.S. trade partners that did not respond. The inclusion of importer-time and exporter-time fixed effects as well as pairwise fixed effects in these models allows us to identify whether responders differentially reduced their imports from the U.S. after Smoot-Hawley, prima facie evidence that a trade war occurred.

Our results show that countries that responded to Smoot-Hawley with retaliatory tariffs reduced their imports from the U.S. by an average of 28-33 percent, while countries that protested 
the implementation of the Smoot-Hawley Tariff also reduced their imports, by between 15 and 22 percent. In other words, de facto retaliation went beyond the group of countries commonly labelled as retaliators.

These findings raise an interesting question: how did responders succeeded in targeting U.S. exports, given that many were bound by their most-favored-nation obligations? One possible answer is quotas, which are by their nature discriminatory, but another is that countries chose to raise tariffs strategically by targeting particularly important exports of the United States, such as automobiles. To test this hypothesis, we construct an additional new dataset, this time of productlevel, quarterly U.S. exports to 59 countries between 1926 and 1932, and use our primary sources to identify key U.S. exports to each trade partner in 1928, before either the Great Depression or the trade war struck. Our gravity model estimates show that retaliators significantly reduced their purchases of key U.S. exports, especially automobiles, after Smoot-Hawley passed. For example, even when controlling for aggregate U.S. exports to particular markets, we show that chief U.S. exports to retaliators were differentially affected, falling by an additional $33 \%$ after the U.S. raised tariffs in 1930 - a result that is consistent with trade partners targeting goods that were of particular importance to the United States. Given that these models include product-time, country-time, and product-country fixed effects, the results also speak directly to the proposed mechanism driving the differential decline in U.S. exports during our sample period: retaliation by U.S. trade partners.

Finally, we calculate changes in the welfare gains from trade, following a recent approach that measures them using changes in the terms of trade. ${ }^{3}$ We find that the welfare gains from trade enjoyed by retaliators fell by roughly $8-17 \%$.

In the next section, we describe the introduction of the Smoot-Hawley tariff bill and the international responses that followed. The discussion highlights the ambiguity characterizing existing research regarding whether particular tariff increases occurring outside the United States constituted retaliation or were essentially autonomous. Section 3 briefly reviews the quantitative literature on the impact of trade restrictions during the 1930s. Sections 4 and 5 ask what made some countries officially protest U.S. policy, or retaliate, while others did not. Section 6 explores the impact of protests and retaliation on trade flows. Section 7 finds evidence that the most

\footnotetext{
${ }^{3}$ See Eaton and Kortum (2002), Arkolakis, Costinot, and Rodriguez-Clare (2012), Arkolakis, Demidova, Klenow, and Rodriguez-Clare (2008) and Felbermayr, Jung and Larch (2015).
} 
important U.S. exports to countries retaliating against it were particularly targeted. Section 8 briefly examines the welfare effects of the Smoot-Hawley trade war and Section 9 concludes.

\section{The Smoot-Hawley Tariff and Retaliation}

The roots of the Smoot-Hawley tariff can be traced back to the First World War. ${ }^{4}$ With European agricultural production depressed due to conflict, it had been a boom time for New World producers, who borrowed heavily to finance expansion. However, as European producers came back online and crop prices fell in response to the increased global supply, a deep recession occurred in the U.S. in 1920-21. Farm incomes remained depressed for the remainder of the 1920s - a decade characterized by lower agricultural prices worldwide. Heavily indebted American farmers found themselves increasingly under pressure, with many losing their farms.

In 1922, the Fordney-McCumber tariff was passed, resulting in a sharp increase in protection, particularly for industrial goods. Democrats and Midwestern Republicans supporting agricultural interests repeatedly called for a leveling of the playing field, arguing that industrial tariffs should be lowered, or agricultural prices raised in order to help farmers; however, it proved difficult to advance either agenda in Congress. Eventually Midwestern Republicans called for higher agricultural tariffs - despite the fact that these would not provide any benefits for those farmers whose livelihoods depended on exporting to the rest of the world. The promise was contained in the Republican platform in the 1928 Presidential election and was endorsed by the victorious candidate, Herbert Hoover.

While Hoover favored focusing on agricultural tariffs, Congress had other ideas. The House Ways and Means Committee did not wait for Hoover's inauguration before getting to work. Under its Republican chairman, Willis Hawley, it began hearings on a new tariff bill in January 1929. The committee eventually produced a bill that raised tariffs on industrial goods more than on agricultural products, hardly what Midwestern Republicans had intended. In May 1929, the House approved the bill, which then went to the Senate Finance Committee chaired by Reed Smoot. The Finance Committee raised some of the proposed tariffs and lowered others, in general moving the legislation in a more agriculture-friendly direction. In September, the full Senate started considering the bill, operating until March 4, 1930 as the so-called "committee of the

\footnotetext{
${ }^{4}$ For an excellent introduction, see Irwin (2011, Chapter 1).
} 
whole." During this phase many industrial tariffs were further reduced. Following this phase, further amendments were made to individual tariff rates, with votes traded between Senators in a manner widely denounced at the time. The final bill reversed many of the tariff reductions that the same Senate, meeting as the committee of the whole, had engineered just a short time previously. The resulting Hawley-Smoot bill, or Smoot-Hawley as Smoot preferred to call it, was signed by President Hoover on June 17, 1930, and came into effect the following day. The legislation raised the average U.S. tariff on dutiable imports by around six percentage points (Irwin, 2017, pp. 38990).

The classic text on trade wars defines them as "a category of intense international conflict where states interact, bargain, and retaliate primarily over economic objectives directly related to the traded goods or service sectors of their economies, and where the means used are restrictions on the free flow of goods or services" (Conybeare, 1987, p. 3). The key concept for identifying a trade war is thus retaliation. If countries around the world decide to raise tariffs for purely domestic reasons, it would certainly be bad for international trade, but according to this standard definition, it would not constitute a trade war. Thus, our primary focus in this paper will be on retaliation. We aim to answer two questions. First, what determined whether countries responded to the U.S., the provocateur in that it was the first that raised its tariffs? And second, what impact did retaliation have on U.S. exports?

In order to answer these questions, we need to clarify further the concept of retaliation in the context of the policy environment. Implicit in the definition of a trade war is the notion that it involves responding to the actions of an instigating country (or set of countries) whose trade policies have harmed or will potentially harm the trade of another country or set of countries ("the potential retaliator(s)"). Thus, in the context of Smoot-Hawley, the U.S. was the instigator and the potential retaliators were those countries that could respond with actions of their own. However, as Irwin (1998b, p. 337) points out, there were three possible responses, only one of which, in our empirical analysis, fits the definition of a trade war. The first was to take "direct retaliatory measures against the United States." The second was to view Smoot-Hawley as a signal that international "policy discipline" had broken down, and erect trade barriers against all countries (a sign of rising protectionism). And the third possibility was not to respond at all which, in the context of the Great Depression, might still involve raising tariffs for purely domestic political reasons. Irwin (1998b) speculates that the second and third possibilities were the most common 
responses to Smoot-Hawley, especially the third option. By our definition, only the first response is what we would consider to be consistent with retaliation resulting from a trade war.

In practice, it has not always been easy to distinguish between these three possibilities since all three, including the third, could represent protectionism. As Kindleberger (1973, p. 132) comments, it can be "difficult to disengage reason from excuse," especially since some of the retaliation may have occurred before Smoot-Hawley came into effect. If a country increased tariffs on U.S. goods but not on other countries 'goods, that would clearly constitute retaliation, but what if it abided by its most-favored-nation (MFN) obligations and did not discriminate against U.S. products? It might still be retaliating if it was purposely targeting goods of particular interest to the United States (e.g. cars); but what if it had wanted to protect its car industry anyway? It is not surprising, then, that as noted below, scholars have disagreed about whether particular foreign responses in fact constituted retaliation. In this paper, we develop an empirical methodology that allows us to identify direct retaliatory effects on U.S. exports and whether key U.S exports, in particular, were targeted.

\section{Previous quantitative literature on the Smoot-Hawley tariff}

Although there is a large scholarly literature on the Smoot-Hawley tariff, only some of it is quantitative. ${ }^{5}$ Several papers ask what drove legislators to vote for Smoot-Hawley: was party affiliation the dominant factor (Pastor, 1980) or did economic interests play an important and independent role (Eichengreen, 1989, Callahan et al., 1994, Cupitt and Elliott, 1994, Irwin and Kroszner, 1996)? Hayford and Pasurka (1992) adopt a different empirical strategy, using industrylevel data to ask what factors led some industries to obtain higher tariffs than others. Although interesting, this literature is not particularly relevant for the present study since we are specifically interested in trade wars and the international responses to Smoot-Hawley, not its domestic political causes.

The conventional view of economic historians who have explored the quantitative effects of 1930 s protectionism is that Smoot-Hawley's contribution to the international trade collapse of 1929-33 was relatively minor. Their basic point is straightforward: the collapse in GDP during the Great Depression was so large that the size of the decline in output and incomes can, on its own,

\footnotetext{
${ }^{5}$ For recent overviews, see Irwin (2011) and the discussion in Irwin (2017).
} 
explain the bulk of that collapse. That is, there is relatively little left for a rise in trade costs to explain. For example, Irwin (1998a) uses aggregate quarterly U.S. import data to estimate a partial equilibrium U.S. import demand function. He finds that, even if ad valorem tariff rates had remained unchanged in the US, imports into that country would have declined by 31.9 percent from the second quarter of 1930 to the third quarter of 1932 - not that much less than the 41.2 percent fall that actually occurred. ${ }^{6}$ Furthermore, movements in the aggregate price level had larger effects on U.S. ad valorem tariff rates than changes in nominal tariffs (Crucini, 1994; Irwin, 1998b).

Given that trade was less than $10 \%$ of total income in an economy like the United States in the late 1920s, it is a fortiori the case that Smoot-Hawley can have had only a small impact on total GDP. Moreover, the qualitative impact of protection on output during the Depression is theoretically ambiguous. Eichengreen (1989), for example, argues that the macroeconomic effects of the Smoot-Hawley tariff on the United States were small, and probably positive, while Irwin (1998b), using computable general equilibrium (CGE) techniques, argues that the welfare impact was small and probably negative. Crucini and Kahn (2003) simulate a dynamic general equilibrium trade model in which there is trade in intermediate inputs. In such a context, tariffs can slow capital accumulation and growth: they estimate that tariffs could have reduced real output by up to 2 percent, but this remains a small effect in the context of the Great Depression. Most recently, a detailed study by Bond et al. (2013) finds that the Smoot-Hawley bill may have lowered U.S. TFP by 0.5 percent - again, not a very large effect in the context of the 1930s. As with the political economy literature on voting, such papers are not particularly relevant for our own work which focuses on the response of countries to Smoot-Hawley.

Economic historians have also concluded that trade policy did not have a great impact on the direction of trade during the 1930s. Eichengreen and Irwin (1995) downplay the role of trade blocs in creating the trade regionalization of the period, which they say was already in motion,

\footnotetext{
${ }^{6}$ Madsen (2001) focuses on interwar trade volumes generally, not U.S. imports specifically. He finds a bigger role for trade policies, but in part this is because he estimates panel regressions where the dependent variables are aggregate trade flows, and because he interprets the time dummies in those regressions (which are, not surprisingly, highly significant) as representing the impact of non-tariff barriers to trade. Jacks and Novy (2019) conclude that trade wars in the interwar period predominantly reinforced existing trade blocks and that bilateral retaliation was rare. Kitson and Solomou (1990) are another dissenting voice, who use single equation time series methods and aggregate data for the United Kingdom. Estevadeordal et al. (2003) and Adam (2019) use gravity methods to explore the impact of tariffs during the 1930s: the former find relatively small effects of tariffs while the latter finds larger ones.
} 
reflecting underlying economic relationships between the countries in question. Wolf and Ritschl (2011) and Gowa and Hicks (2013) reach similar conclusions. More recently, however, de Bromhead et al. (2019) have used commodity-level data on trade flows and policies to study the impact of the UK's switch to protection after 1931: this explains only around a quarter of the decline in aggregate UK imports (similar to what Irwin found for the U.S.), but it also explains the majority of Britain's shift towards Imperial imports during the period. ${ }^{7}$

None of these papers addresses the quantitative impact of the response of other countries to the Smoot-Hawley tariff - the focus of our research. ${ }^{8}$ It might very well be the case that SmootHawley contributed relatively little to the aggregate decline in trade or production, but that retaliation significantly impacted U.S. exports with trade partners that chose to participate in a trade war. Our empirical analysis aims to fill this major gap in the literature.

\section{Foreign Responses to Smoot-Hawley}

The U.S. threat to raise tariff rates was initially met with protests by a large number of countries and British colonies. As Smoot-Hawley wound its way through Congress, 20 foreign governments urged the U.S. government to reconsider, lodging official complaints with the U.S. State Department between February and June of 1929. The Hoover administration refused to make the number and names of these petitioners public, so the U.S. Senate passed a resolution requiring the U.S. State Department to submit all formal complaints of countries protesting the proposed tariff increases to the U.S. Senate Finance Committee. These were then read into the public record during the official debate on the Smoot-Hawley legislation. By the fall of 1929, the number officially protesting the tariff bill had grown to 35 colonies and countries, including some of the United States' largest trade partners: the United Kingdom, Germany, and Japan (see Tables 1 and 2). ${ }^{9}$ Canada was the exception to this protocol. Given their close geographical proximity as well as the importance of bilateral trade between the two nations, the Canadian government appealed directly to President Hoover on March $15^{\text {th }}, 1929$ (Kottman, 1975). ${ }^{10}$

\footnotetext{
${ }^{7}$ Arthi et al. (2020) reach similar conclusions for interwar India.

${ }^{8}$ Indeed, Eichengreen (1989) concludes that without a quantitative assessment of major trading nations, it is unclear whether countries retaliated in response to Smoot-Hawley.

${ }^{9}$ We include the countries whose protest letter are included in the Hearings before the Committee on Finance on HR.2667, which includes all communication received before September $5^{\text {th }}, 1929$.

${ }^{10}$ In our empirical exercises we thus code Canada as a protester.
} 
Protesting countries and colonies represented the interests of domestic industries whose exports would be harmed by tariff increases (leather goods from Austria, bananas and coffee from Guatemala, tomatoes and olive oil from Italy, woolen goods from the United Kingdom, etc.). For example, early as February 1929 Australian exporters of meat and wool called on Prime Minister Stanley Bruce to take action and urged that he retaliate by increasing tariff rates on American automobiles. $^{11}$

Protesting countries also explicitly drew attention to bilateral trade balances. More than 60 percent of the initial set of protesters argued that the U.S. ran a favorable bilateral balance of trade with them and that the tariffs were therefore unnecessary - a complaint made by some responders in more recent examples of trade wars. For example, the New York Times reported on June $15^{\text {th }}$, 1930, that a prominent newspaper in Uruguay called for a prohibitive tariff on U.S. automobiles stating that: “Uruguay's exports to the United States in 1928 were valued at \$10,000,000, while she imported from the United States in the same year products valued at \$29,000,000, of which 40\% were automobiles and fuel. La Mañana holds that the restriction of automobile imports would affect nobody except those with a frivolous idea of luxury who spend for automobiles huge sums bearing no relation to their true wealth." 12

The protests were to no avail. Smoot-Hawley passed Congress and was signed by President Hoover. The official trade war began when countries responded by targeting U.S. goods with new trade taxes. As the League of Nations documented, "The Hawley-Smoot tariff in the United States was the signal for an outburst of tariff-making activity in other countries, partly at least by the way of reprisals. Extensive increases in duties were made almost immediately by Canada, Cuba, Mexico, France, Italy, and Spain" (League of Nations, 1932, p.193). For example, a month after Smoot-Hawley's passage, Spain adopted the Wais Tariff (named after its finance minister), targeting automobiles, tires, and motion picture equipment with new duties - products that overwhelmingly came from the U.S. and were not produced by Spain (Jones, 1934). To shed some light on the political economy of this trade war, the next section examines which countries responded and provides some reduced-form evidence on the political and economic characteristics of American trade partners that petitioned and retaliated against U.S. imports in response to SmootHawley.

\footnotetext{
${ }^{11}$ New York Times, February $10^{\text {th }}, 1929$.

${ }^{12}$ New York Times, June $15^{\text {th }}, 1930$.
} 


\section{Analyzing the Characteristics of Protesters and Retaliators}

A full list of countries responding to Smoot-Hawley is shown in Table 2. Protesters filed official petitions with the U.S. State Department in 1929, in response to the proposed tariff bill. Retaliators are U.S. trade partners listed by Mann (1930) as imposing tariffs on U.S. exports in response to Smoot-Hawley. ${ }^{13}$ Since most retaliators also protested the tariffs, we additionally define "threateners" as the subset of protesters not retaliating. Threateners made up 43\% of total U.S. trade in 1928 while retaliators constituted $38 \%$ of total U.S. trade. Tables 1 and 2 show that 9 of the 10 largest recipients of U.S. exports, and 7 out of the 10 largest exporters to the U.S., petitioned the U.S. State Department. 6 of the 10 largest recipients of U.S. exports retaliated.

A prime example is Canada, which McDonald et. al. (1997) characterize as being engaged in a trade war after the passage of Smoot-Hawley. With 43 percent of its exports going to the U.S., the U.S.'s neighbor to the north aggressively responded to Smoot-Hawley by twice raising its duties on U.S. goods in 1930. It first lowered duties on 270 goods imported from the British Empire and then imposed countervailing duties on 16 American products, accounting for nearly one-third of U.S. exports to Canada. Then, after the Conservative government won an election held in July and characterized by anti-U.S. trade sentiment, it passed an "emergency tariff" - raising import duties on textiles, agricultural implements, electrical equipment, and meat - most of which came from the U.S. Canada also imposed anti-dumping duties and administrative measures directed against U.S. products (Mann, 1958).

Other countries also retaliated against the U.S. in the wake of the passage of Smoot Hawley. France raised its tariffs on some of its largest imports from the U.S. in 1930, including automobiles and parts in April (which was ranked $5^{\text {th }}$ in terms of U.S. imports) and lard (which saw its rate double) (Bidwell, 1930, p. 24). The fact that France changed the tariff on automobiles from a value basis to a weight-basis was seen by contemporaries as a direct reprisal against the U.S. "These rate

\footnotetext{
${ }^{13}$ Mann was writing in 1930, the year that Smoot-Hawley was passed. He thus included in his list countries that were preparing to retaliate, such as Argentina, or whose governments were facing pressure to retaliate, such as Uruguay. Jones (1934) and other sources listed below later provided corroborating evidence of retaliation. On the other hand, Eichengreen (1989) doubts whether retaliation was always involved. The evidence in Section 6 speaks to this issue indirectly, asking whether countries listed by Mann as retaliating, or threatening to retaliate,

disproportionately reduced their imports from the United States. The evidence suggests that Mann's judgments were sound. Note that trade flows to or from Uruguay and Paraguay were reported jointly by several countries, so we were obliged to treat these as one entity when constructing our gravity dataset.
} 
changes resulted in increases of almost 50 per cent for some models and practically closed the French market to medium-priced American cars." (Mann, 1930, p.276). In Italy, immediately following the passage of Smoot-Hawley, the duties on automobiles were also raised - by between 100 and 167 percent. On July 23, 1930 Spain increased customs duties on automobiles, sewing machines, bicycles, motorcycles, pneumatic tires, razor blades, and paints, most of which were primarily imported from the United States. It also rewrote its tariff schedule to charge higher duties on non-European automobiles and parts, leading American sales representatives in Spain to reduce "their personnel in anticipation of a substantial curtailment of sales" (Mann, 1930, p.275).

U.S. trade partners found additional ways to retaliate against the passage of Smoot-Hawley, including quotas and boycotts of U.S. products. For example, the Royal Italian Auto Club took out newspaper ads calling for a boycott of American cars, branding consumers of U.S. products as unpatriotic (Bidwell, 1930, p. 26). In South America, the widely circulated newspaper, $L a$ Mañana, called for a continent-wide boycott of prominent American consumer goods, such as automobiles, as did organizers in Argentina. The Federation of Uruguay Rural Societies urged the government to place restrictive taxes on automobiles and also to consider banning them altogether as part of a program of reprisal against the United States (Mann, 1930, p.275). Similarly, several Swiss chamber of commerce chapters filed resolutions calling for boycotts of American products such as typewriters and autos (Jones, 1934, p. 112, Mann 1930). And in Czechoslovakia, the country may have imposed a quota on U.S. automobile imports in response to Smoot-Hawley (Eichengreen, 1989). As discussed in Sections 6 and 7 of the paper, our data and econometric estimates will allow for the possibility that responses by trade partners may have included nontariff barriers as well as the targeting of key American exports.

To better understand the characteristics of responders, we analyze the trade and political relationships countries had vis-à-vis the U.S. just prior to the onset of the trade war. Our probit model includes economic factors highlighted in the existing literature on trade wars or mentioned in the protests filed by trade partners in response to the American decision to consider tariff revisions in 1929: a country's bilateral trade balance with the U.S. in the three years 1926-8; the country's overall trade balance in the same years (both as a share of the country's total trade); and exports to the U.S. as a share of total exports in $1928 .{ }^{14}$ The probit model also includes a number

\footnotetext{
${ }^{14}$ We use the trade data of Gowa and Hicks (2013). We thank Raymond Hicks for graciously providing us with the data.
} 
of political economy variables that have been identified by economic historians as potential drivers of trade policy: a country's political regime (polity), proxied by a 21-point measure (where higher numbers indicate a more democratic and less authoritarian regime); a dummy variable indicating whether or not the country had an existing most-favored-nation (MFN) agreement signed with the U.S. in 1928; and a dummy variable indicating whether the country had outstanding external official debt arising from World War I. ${ }^{15}$ We estimate the following equation:

$$
\begin{aligned}
& \text { (1) }\left\{\text { Responder }_{i}\right\}=\alpha_{0}+\beta_{1} \text { US Export Share }{ }_{i, 1928}+\beta_{2} \text { Trade }_{\text {Balance }}{ }_{i, 1926-28} \\
& +\beta_{3} \text { Trade Balance vs US } S_{i, 1926-28}+\beta_{4} \text { MFN Agreement }{ }_{i}+\beta_{5} \text { Polity Score }_{i} \\
& +\beta_{6} \text { IndebtednessDummy }{ }_{i}+\beta_{7} \text { Continent Dummy }+\epsilon_{i} \text {, }
\end{aligned}
$$

where the binary dependent variable (responder) takes on a value of 1 when an economy filed a formal complaint with the U.S. State Department during the debate on Smoot-Hawley, or when countries imposed retaliatory tariffs in response to the passage of Smoot-Hawley.

The last column of Table 3 presents empirical estimates of equation (1), with Huber-Whitesandwich robust standard errors shown in parentheses. Although many protesting trade partners drew attention to their trade position vis-à-vis the U.S. in their formal complaints, the estimated coefficients do not support the idea that countries running large bilateral trade deficits with the United States were more likely to lodge an official complaint or to retaliate with a tariff. Indeed, several petitioners ran bilateral trade surpluses with the U.S. (e.g., the UK, Australia, and Cuba). The coefficient on the bilateral trade balance is statistically insignificant, and when the other two trade-related variables are omitted, its sign actually becomes positive. Nor is a country's export dependence on the U.S. robustly correlated with being a responder, although it has the expected, positive sign.

On the other hand, the overall trade balance is positively associated with responder status: countries running larger trade surpluses were more likely to respond. Countries running trade surpluses may have had more to lose from protectionism elsewhere, and export interests in those countries may have been more politically powerful as well.

\footnotetext{
${ }^{15}$ For polity data, see: $\mathrm{http}: / /$ www.systemicpeace.org/inscrdata.html. Information on MFN clauses comes from Tariff Bargaining under Most-Favored-Nation Treaties, Letter from the Chairman of the United States Tariff Commission, U.S. Government Printing office, Washington, 1934. War debts are from The War Debts, Supplement to the Economist, November 12, 1932. The lion's share of World War I debts were official debts directly or indirectly owed to the U.S., a net creditor.
} 
The probit models also suggest that more democratic countries (those with higher polity scores) were more inclined to petition the U.S. government. A one-unit increase in the polity score raises the probability of protesting by around $14 \%$ percent. Intense lobbying by industries may have been particularly effective in countries with democratically-elected officials, and industries may have had a greater incentive to establish effective lobbying in democratic societies (consistent with Grossman and Helpman, 1994). The Congressional Record contains 250 pages of filings from 35 governments, protesting against 300 specific items in the 1929 Tariff Bill, including cigar and cigarette holders (Austria), imitation pearls (Spain), granite, bread \& matches (Finland), shoes (Czechoslovakia), and lacework, watches and clocks (Switzerland). This is consistent with industry lobbying. Other political-economy variables, such as indebtedness to the U.S. (as a result of World War I) and MFN agreements with the U.S. do not appear to play a role in a country's response to Smoot-Hawley.

\section{The effects of Retaliation on Trade Flows}

\section{A. Time Series Evidence}

In contrast to protectionism (and as discussed in Section 2), trade wars involve tariffs or other trade barriers applied in retaliation against the actions of a particular trade partner. In this section, we thus focus on what happened to U.S. exports after retaliatory tariffs and other barriers were imposed by its trade partners in response to the Smoot-Hawley tariff. To do so, we construct a new quarterly panel data set of bilateral trade flows between 1925-1938 for 99 economies, 55 of which were sovereign countries.

The unbalanced panel contains 108,722 raw observations on bilateral import flows. The country sample is based on the availability of high-frequency bilateral data from domestic sources. A full list of country sources can be found in Appendix A. In total, our data account for 30,688 million USD of total imports for all sample countries in 1928. Since according to the League of Nations total global imports stood at 34,475 million USD in 1928 , this represents $89 \%$ of world imports. ${ }^{16}$ Where necessary, we take advantage of "duplicate" observations (i.e., the fact that exports from country $i$ to country $j$ can also be represented as imports into country $j$ from country

\footnotetext{
${ }^{16}$ League of Nations, Memorandum on International Trade and Balances of Payments, Vol 2, 1926-28.
} 
i) to obtain the largest possible number of bilateral export pairs and to check the reliability of our quarterly data. In constructing our data set, wherever possible, we follow the procedures and best practices for gravity data outlined in Head et al. (2010). For example, our first choice is to use import data rather than the equivalent export data; when constrained to use export data, we add 10 percent to the value to take account of the fact that exports are reported FOB, while imports are reported CIF. ${ }^{17}$ Full details on the data sources for the individual countries are provided in Appendix A. Given that the early 1930s were characterized by several severe shocks, the quarterly frequency of our data is particularly important for accurately estimating the effects of retaliatory tariffs.

Figure 1 summarizes one important aspect of the data by displaying time-series graphs of aggregate nominal U.S. exports to and imports from responders and non-responders. Responders consist of both retaliators and threateners. Non-responders are trade partners in our sample that neither protested, threatened, nor retaliated. The first panel of Figure 1 shows that U.S. exports declined after the passage of Smoot-Hawley (marked by the vertical line indicating June 1930). U.S. exports to responders experienced a steeper decline than did exports to non-responders consistent with the notion that there may have been retaliation. Figure 1 also highlights the fact that responders made up the bulk of U.S. exports before the passage of Smoot-Hawley - about 80 percent. What happened in their markets thus had a major impact on total U.S. trade. By contrast, the second panel of Figure 1 shows that U.S. imports declined in a roughly similar manner across the two groups of countries. This pattern is consistent with falling U.S. demand, in general, as well as with an increase in the general level of U.S. protection. It does not suggest that responders' exports were differentially affected. To unpack these trends further, Figure 2 disaggregates the responders, displaying U.S. exports by country of destination for both retaliators and threateners. All retaliators show a sharp decrease in imports from the U.S. after Smoot-Hawley. The response for the group of countries that filed petitions with the U.S. state department, but then did not retaliate, the threateners, looks more mixed, but overall shows a similar drop in countries' imports from the U.S.

\footnotetext{
${ }^{17}$ We use the Global Financial Database to convert trade data to \$ US, supplemented with data from Obstfeld, Shambaugh and Taylor (2004) for Bulgaria.
} 


\section{B. Estimating the Effects on Bilateral Import Flows}

Assessing whether the Smoot-Hawley trade war had an impact on trade flows means testing whether, ceteris paribus, U.S. exports differentially fell by more for trading partners that retaliated than for those that did not respond. As is standard in the literature we use a theoretically wellfounded gravity model to estimate the impact of retaliation on U.S. exports. In particular, we estimate either:

$$
\ln \left(I M_{i j t}\right)=\alpha+\gamma_{1} \text { Responder }_{i j t}+\eta_{k} \text { Controls }_{i j t}+d_{i t}+d_{j t}+d_{i j}+\varepsilon_{i j t}
$$

or

$$
\begin{aligned}
\ln \left(\text { IM }_{i j t}\right) & =\alpha+\gamma_{2} \text { Retaliator }_{i j t}+\gamma_{3} \text { Threatener }_{i j t}+\eta_{k} \text { Controls }_{i j t}+d_{i t}+d_{j t}+d_{i j} \\
& +\varepsilon_{i j t}
\end{aligned}
$$

The dependent variable, $I M_{i j t}$, is the log of country $j$ 's imports from country $i$ in quarter $t$. The independent variables of interest are time-varying, trade pair-specific indicator variables that take the value 1 when country $i$ is the U.S. and when country $j$ is a trade partner of the U.S. that retaliated against Smoot-Hawley (retaliator), filed a petition in response to the proposed U.S. tariff bill of 1930 but did not retaliate (threatener), or did either (i.e. the union of the two previous groups) (Responder). These variables switch on in the quarter when protests were filed or retaliation occurred and remain equal to 1 thereafter unless otherwise specified. As noted previously, coding these as indicator variables allows us to account for both tariff and non-tariff barriers to U.S. exports.

The estimation equation includes a number of time-varying, pairwise institutional features (Controls $s_{\mathrm{ijt}}$ ) of the global trade environment of the interwar period, which may also have affected U.S. exports during our sample period. These controls include whether both economies in the bilateral trade pair were part of the Sterling Bloc, Reichsmark Bloc, Gold Bloc, or Imperial Preference system, and whether countries had signed a reciprocal trade act with the United States in 1934 or subsequently (RTAA). We also include variables indicating whether at least one economy in a given bilateral trade pair was involved in the Anglo-Irish Trade War, and whether 
two countries in a pair were simultaneously experiencing a financial crisis during a quarter. ${ }^{18}$ And, as is now standard in the estimation of structural gravity models, we include exporter-time $\left(d_{i t}\right)$ and importer-time $\left(d_{j t}\right)$ fixed effects, allowing us to control for a long list of potential confounders that are time-varying but country specific (e.g. other policy responses, including increases in general levels of protection targeting all countries) as well as other factors influencing multilateral resistance. We also include pair fixed effects $\left(d_{i j}\right)$ that allow us to control for a variety of other factors, including World War I debts owed by particular countries to the U.S. Identifying variation thus comes from time-varying imports for a given trade pair.

Table 4 presents OLS estimates of equations (2) and (3) (using positive observations only) as well as Poisson pseudo-maximum likelihood (PPML) estimates, following Santos Silva and Tenreyro (2006). The OLS results in Column 1 display the difference between all countries that responded in one way or another to the 1930 U.S. Tariff Act, and those that did not (with nonresponders as the omitted category). The coefficient on responder is negative and statistically significant, with the coefficient showing that exports from the U.S. were, on average, 25 percent lower when a trade partner protested or retaliated in response to Smoot-Hawley. ${ }^{19}$ Using the PPML specification (column 2), the differential effect on U.S. exports for responders remains negative and statistically significant at the one-percent level. Although the coefficient is somewhat smaller than in the OLS specification, the effect is still sizable, indicating a roughly 18 percent decline. The last two columns examine specifications for the two sub-categories of responders: threateners and retaliators. Non-responders are once again the omitted category. As might be expected, exports from the U.S. fall by even more when we focus only on the trade partners that retaliated, declining by between 28 and 33 percent depending on the regression specification. The measured average decline in U.S. exports to retaliators is consistent with the limited evidence available from country case studies ${ }^{20}$ It is interesting that the average threatener reduced its imports from the U.S. by between 15 and 22 percent after it protested Smoot-Hawley - a finding that suggests that de facto retaliation may have taken place even among countries not traditionally thought to have

\footnotetext{
${ }^{18}$ The Anglo-Irish Trade war lasted from 1932-38. See O’Rourke (1991) for details. The crisis variable indicates whether both trade partners are simultaneously experiencing banking crises, as defined in Reinhard and Rogoff (2009), and adjusted where possible for quarterly dates based on Bernanke and James (1991). If no end date could be identified, banking crises were coded for four quarters.

$19100 *(1-\exp (-0.287))=25$ percent.

${ }^{20}$ For example, Irwin (2011, p.158) estimates that Canada's 1930 tariffs potentially reduced U.S. exports by $21 \%$.
} 
done so. This is consistent with the historical evidence presented above on Czechoslovak nontariff reprisals, as well as with empirical findings in the anti-dumping literature, suggesting that the threat of countervailing duties being imposed can be sufficient to induce changes in trade (Staiger and Wolak, 1994).

\section{Robustness Checks and Extensions}

We perform a variety of robustness checks on our gravity model. First, we explore whether countries' colonial ties might be magnifying the response since not all polities in our analysis made independent trade-policy decisions. We repeat our gravity regressions for non-colonies (Table 5), which reduces the sample to 59 sovereign nations. The coefficients on responders, retaliators, and threateners remain negative and statistically significant. In fact, the effect for sovereign countries is larger than for the full country sample, with responders reducing imports from the U.S. by 42$47 \%$, threateners reducing them by $31-39 \%$ and retaliators reducing them by $57-62 \%$.

Next, to test whether any single country is driving the result, we eliminate each retaliator from the sample and re-estimate the model (Table 6). The average effect on U.S. imports remains and changes little, regardless of which retaliator is dropped, confirming our main result. Because two of the retaliators devalued in the same year as Smoot-Hawley (Uruguay and Argentina) we jointly drop them from the sample and re-estimate the effects. In this specification, both the coefficients on retaliator and on responder remain negative and statistically significant at the 1percent level and 10-percent level, respectively (again, see Table 6).

Finally, to further our understanding about which sets of trade partners were driving the results, we split the sample of retaliators into three groups: (1) countries that imposed imperial preferences (Canada and Australia); (2) those that were part of the gold bloc (France, Italy, and Switzerland); and (3) the rest (Argentina, Cuba, Mexico, Spain, Uruguay and Paraguay). Table 7 displays the results. For all three groups the results remain negative and statistically significant. We see the strongest retaliator effect for the imperial preference countries, followed by the Latin American countries and Spain. It appears that members of the British Empire were particularly effective at reducing trade with the U.S.; this is consistent with de Bromhead et al. (2019) and Arthi et al. (2020), who find that British and Indian trade policies induced a substitution towards imports from the Empire, at the expense of imports coming from elsewhere in the world. 


\section{Strategic Responses to Smoot Hawley}

A trade war broke out when trade partners retaliated specifically against the U.S. in response to Smoot-Hawley. We have found that retaliators, and perhaps more surprisingly threateners, disproportionately reduced their imports from the United States. In order to accomplish this, policymakers in these countries presumably targeted specific U.S. products for duties or other trade restrictions (boycotts, quotas, etc), rather than raising duties on all countries' products in a non-strategic manner (as in general protectionism). Today, targeting another country's products in a trade war is often done with strategic intentions. For example, in 2017-18, China retaliated against the Trump administration's tariffs on its goods by raising duties on key products produced in states that were "electorally sensitive" and/or main exports to China (e.g., agricultural goods). In other words, in a trade war, any differential effects would be observable both at the country and the product level. ${ }^{21}$

The narrative evidence presented in Sections 4 and 5 suggests that strategic retaliation took a number of forms. For example, Czechoslovakia restricted automobile imports to 750 units from each of its most favored nations; although in principle this action was non-discriminatory, the quota was binding for the US, but non-binding for European trade partners such as France (Eichengreen, 1989). Quotas could also be set in an explicitly discriminatory manner. Overt discrimination was more difficult when it came to tariffs, given countries' MFN obligations. Countries could get around this, however, by raising tariffs disproportionately on key U.S. exports. Higher tariffs on movies, cars, and other goods disproportionately supplied by the United States might in principle apply equally to all trade partners, consistent with the non-discrimination principle, but in practice particularly hit U.S. exports. ${ }^{22}$

To test whether trade retaliation involved targeting key imports from the U.S. in a strategic manner, we constructed a second panel data set of 27,840 quarterly observations, consisting of 104 U.S. product categories exported to 59 trade partners from 1926:III through 1932:II. Taking 1928

\footnotetext{
21 The narrative evidence does not seem to indicate that retaliators took the additional step of targeting products from specific states. More than likely, there would have been little short-term gain to adopting this additional strategy as Hoover had just been inaugurated as President on March 4, 1929.

${ }^{22}$ British Empire countries bypassed their MFN obligations in a more straight-forward manner, arguing that Imperial Preference did not breach the principle of non-discrimination.
} 
as the benchmark, the product level dataset comprises $35.6 \%$ of all U.S. exports in 1928 and captures the most important U.S. export partners in each product category. It is therefore weighted toward the most important U.S. export destinations and - again taking 1928 as a benchmark includes $42 \%$ of U.S. exports to Canada in 1928, 47\% of U.S. exports to the United Kingdom, and $34 \%$ of U.S. exports to France. We hand collected data from the U.S. Department of Commerce's United States Monthly Summary of Foreign Commerce. These bilateral-product level data allow us to examine more precisely whether threateners and retaliators disproportionately targeted particular imports arriving from the U.S. after Smoot Hawley, and, if so, by how much. More precisely, the product-level data allow us to construct a measure of "strategic" targeting, specific to each trade partner. We identify the top 10 exports from the U.S. to each country or colony in our data set as reported by the U.S. Department of Commerce. We then estimate the following equations using PPML:

(4) $\ln \left(E X_{i j t}\right)=\alpha+\delta_{1} \operatorname{Top}_{10} 0_{i j} *$ Responder $_{j t}+d_{i t}+d_{j t}+d_{i j}+\varepsilon_{i j t}$, and

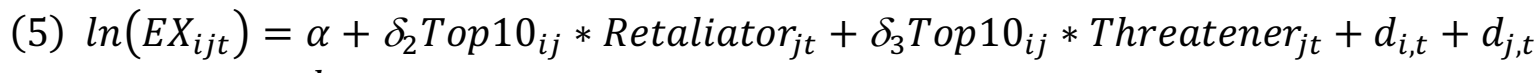
$+d_{i, j}+\varepsilon_{i j t}$.

$E X_{i j t}$ is exports of good $i$ to country $j$ in period $t$;op $10_{i j}$ is a dummy variable indicating whether, in 1928, good $i$ was among the top ten U.S. exports to country $j$. As in Section 6, Responder Retaliator $_{j t}$, and Threatener $_{j t}$ indicate whether country $j$ was a responder, retaliator, or a threatener in period $t$. The $d$ 's represent product-time, country-time, and product-country fixed effects. As a result, the identifying variation in U.S. exports is at the product (group)-trade partnertime level.

We estimate equations (4) and (5) using PPML and the results are reported in Table 8. $\delta_{1}$, $\delta_{2}$ and $\delta_{3}$ are estimated to be equal to $-0.255,-0.396$ and -0.224 , respectively. ${ }^{23}$ Thus, even when controlling for aggregate U.S. exports to particular markets $\left(d_{j t}\right)$, the regression estimates show that the most important U.S. products exported to responders were disproportionately affected. On

\footnotetext{
${ }^{23}$ The results are not sensitive to using a cut off of "top 5" or "top 3" exports to a trade partner. They are based on the product groups that can be consistently identified and do not change labelling or product classification between 1926-1932. Using a broader product classification, allowing for name changes and some re-grouping does not fundamentally alter the results.
} 
average, chief U.S. exports to retaliators fell by an additional 33\% after Smoot Hawley and by an additional $20 \%$ for threateners. Aggregating retaliators and threateners, the main exports to the average responder dropped by an additional $22.5 \%$ after Smoot-Hawley. These results are consistent with countries targeting goods that were of particular importance to the United States. A coefficient of the order of 0.2 , combined with a trade elasticity of around 5 (see the following section), could imply that tariffs on top U.S. exports were increased by around 4 percentage points more than tariffs generally. We stress, however, that our results do not preclude the possibility of overt discrimination, either via imperial preferences, or via non-tariff barriers to trade, such as quotas and boycotts (both mentioned in the narrative evidence).

As discussed in Sections 4 and 5, one U.S. export that may have been singled out for potential retaliation by multiple countries and repeatedly mentioned in contemporary accounts is automobiles - a fast growing and important U.S. export (Mann, 1930). Chrysler, Ford, and General Motors were highly visible, American brands sold globally. And, unlike many other leading U.S. exports, such as copper, cotton, and petroleum, autos were differentiated products, easily identifiable in their final form. They were also consumer rather than producer goods, so restricting their supply did not risk hurting domestic industries. Tariffs, quotas, and boycotts of U.S. autos may have thus been a particularly effective way of carrying out trade reprisals directed at American exports.

To test this additional form of targeting, Panel B of Table 8 adds triple-interaction terms to equations (4) and (5), where the Top $10 *$ (retaliator/threatener/responder) terms are interacted with the product category, automobiles and other vehicles. Consistent with the historical evidence, we find an additional negative and statistically significant effect on the triple interaction term. As might be expected, the largest coefficients involve the retaliator dummy (column 2). The coefficient on the $\operatorname{Top} 10_{i j}{ }^{*}$ retaliator*automobiles interaction is -0.613 , indicating that retaliators reduced their automobile imports from the U.S. by an additional $46 \%$. That said, the effect is also statistically significant in specifications using threatener and responder dummies. Our results suggest that while it may have been weaker, de facto retaliation, such as the aforementioned Czech automobile quotas, occurred in a broader range of countries than sometimes assumed. ${ }^{24}$

\footnotetext{
${ }^{24}$ Prior to Smoot-Hawley, autos were consistently a top 10 export from the U.S. to countries in the retaliator group. Examples include: Canada $\left(2^{\text {nd }}\right)$, Argentina $\left(1^{\text {st }}\right)$, Uruguay $\left(1^{\text {st }}\right)$, Spain $\left(2^{\text {nd }}\right)$, France $\left(5^{\text {th }}\right)$, Italy $\left(10^{\text {th }}\right)$, Cuba $\left(4^{\text {th }}\right)$, and Mexico $\left(2^{\text {nd }}\right)$.
} 


\section{Welfare Effects}

What were the welfare effects of the Smoot Hawley trade war? As stressed earlier, the welfare consequences of protection during a period of mass unemployment such as the Great Depression are ambiguous. On the one hand, tariffs raise revenue and protect domestic industries by raising the price of foreign goods, which may have increased welfare (Eichengreen, 1989, Clemens and Williamson, 2004). On the other hand, welfare gains due to beggar-thy-neighbor effects would have presumably been diminished or eliminated by the retaliation that is the focus of this paper. ${ }^{25}$ Recent research provides new methods for measuring the gains from trade and evaluating the welfare consequences of past trade policy shocks (Eaton and Kortum, 2002, Arkolakis, Costinot, and Rodriguez-Clare, 2012 and Arkolakis, Demidova, Klenow, and Rodriguez-Clare, 2008, Felbermayr, Jung and Larch, 2015). Relative to other computational methods, the elegance of the approach lies in its simplicity and the fact that it applies to a wide class of one-sector trade models that are popular in the literature and that differ with respect to their assumptions about microeconomic structure.

A basic insight from this literature is that changes in income due to trade shocks depend on changes in the terms of trade. For a given country, changes in the terms of trade, relative to each of its trade partners, can be surmised from the trade elasticity (i.e., one minus the elasticity of substitution across goods). Under certain assumptions spelled out in Arkolakis, Costinot, and Rodriguez-Clare (2012) (hereafter, ACR), calculating welfare depends only on (1) the domestic trade share (a country's trade with itself) and (2) the elasticity of trade (measured using a gravity equation). This formulation, however, ignores the welfare consequences of tariffs, which affect real income directly and indirectly (through the entry and exit of firms). Since tariffs are clearly central to our analysis and discussion of the 1930s, we modify the ACR formula using the methods discussed in Felbermayr, Jung and Larch (2015) (hereafter, FJL). ${ }^{26}$ We measure gains from trade in country $j, G_{j}$, relative to autarky, as:

\footnotetext{
${ }^{25}$ Crucini and Kahn (2003) also make the point that retaliation could wipe out welfare gains, and in the case of the U.S., argue that retaliation led to higher input costs for U.S. manufacturers, leading to production distortions.

${ }^{26}$ In their model, ad valorem tariffs redirect consumption toward domestic goods and revenues are lump-sum transfers to consumers. Tariffs can act as either "cost shifters" or "demand shifters."
} 
(6) $G_{j}=1-\mu_{j}^{-\left(1+\frac{\delta \eta}{\varepsilon_{\tau}}\right)} \lambda_{j j}^{\frac{1}{\varepsilon_{\tau}}}$

where $\varepsilon_{\tau}$ is the trade elasticity of demand, $\lambda_{j j}$ is the domestic expenditure share, and $\mu_{j}$ is a tariff multiplier. $\lambda_{j j}$ can be computed as 1 minus the import penetration ratio, which is calculated as imports as a share of domestic expenditure. ${ }^{27}$ Since equation (6) calculates welfare changes relative to autarky, we use it to calculate the welfare gains from trade in 1929, 1930 and 1931, and then difference between periods to estimate the effect of Smoot-Hawley. As FJL show, the tariff multiplier, $\mu_{j}$ does not require information on bilateral tariffs or bilateral trade flows and can be computed as the share of aggregate tariff revenue in aggregate income. The gains from trade depend on the term $\delta \eta$. We follow FJL and present results for two cases: $\delta \eta=0$ (corresponding to the Armington, Eaton and Kortum and Krugman models) and $\delta \eta=0.65$ (corresponding to the Melitz model).

To obtain a value for $\varepsilon_{\tau}$, the trade elasticity, we follow Anderson and van Wincoop (2004) and estimate a gravity equation of the following form:

(7) $\ln X_{i j t}=A_{i t}+B_{j t}+\varepsilon_{\tau} \ln \tau_{i j t}+v_{i j t}$

where $A_{i t}$ is an exporter-specific term; $B_{j t}$ is an importer-specific term; and $v_{i j t}$ captures countrypair-specific parameters that are distinct from variable trade $\cos t s \tau_{i j t}$ (if any). Since Jacks, Meissner, and Novy (2008) explicitly estimate trade costs, and for external validity, we employ their database of annual trade data for the interwar period to estimate equation (5). ${ }^{28}$ Estimation of the interwar gravity model produces a value of $\varepsilon_{\tau}$ of -4.76 , which is in the range of those surveyed in the literature for the modern period (Anderson and Van Wincoop, 2004).

Panels A and B of Table 9 display average changes in welfare for the two types of models and for different groups of belligerents (retaliators, threateners, and the instigator, the United States) between the quarters immediately before the passage of Smoot-Hawley and those just after.

\footnotetext{
27 The import penetration ratio is computing using total quarterly imports and exports from our data set and GDP figures from the Jorda-Schularick-Taylor Macrohistory Database. Their GDP are not as inclusive as our trade data, and so the number of countries we include in our welfare analysis is smaller.

${ }^{28}$ We thank David Jacks and Chris Meissner for generously sharing their data for use in this calculation.
} 
In computing welfare effects, we use the actual domestic expenditure shares before and after Smoot-Hawley. As emphasized in the literature, this formulation of welfare shuts down a number of other sources of welfare gains from trade. As a result, much like modern empirical estimates, the baseline values of gains of trade, relative to (counterfactual) autarky are small - in the range of 1 to $5 \%$ for 1929 , our baseline year, and even when tariffs are included. Because the total gains from trade using this methodology are small, changes due to an increase in protection will be even smaller. The table thus displays welfare changes relative to 1929, not only as percentage changes in welfare, but as percentages of the total welfare gains from trade.

The calculations suggest that, for retaliators, welfare declined by 0.3 percentage points between 1929 and 1930, corresponding to a reduction of $8 \%$ in the total welfare gains from trade. Between 1929 and 1931, welfare declined by roughly 0.6 percentage points or $17 \%$ of the total welfare gains from trade. For threateners, the welfare effects are small but positive, while for the U.S, they are even smaller, and of mixed signs. As FJL explain, conditional on observed tariff multipliers and domestic expenditure shares, gains from trade are larger in the Melitz model than in other quantitative trade models, so the effects in Panel B are slightly larger as a result.

As noted by previous scholars, the tariff of 1930 that provoked the trade war was substantial and broad based though not necessarily an optimal tariff, even for a large economy like the U.S. (Crucini and Kahn, 1996), and it provoked a significant retaliatory response from U.S. trade partners, largely negating any welfare gains based on our calculations through 1931 - a finding consistent with Irwin (2011). Retaliating countries suffered welfare losses, perhaps because they did not impose "optimal tariffs," but rather retaliatory tariffs targeting key U.S. products, such as autos. Another possible explanation is that retaliators may have been particularly impacted by other shocks affecting domestic expenditure shares at this time, such as Smoot-Hawley itself.

\section{Conclusion}

President Trump's recent use of tariffs as a "weapon" to cudgel other nations into changing their trade policies has renewed interest in understanding what trade wars are and how they affect flows of goods and services across borders. As our research indicates, the current trade war was by no means the first one initiated by the U.S. The passage of Smoot-Hawley led to direct retaliation by important U.S. trade partners. Countries responded to its passage by imposing tariffs 
targeting U.S. exports. Although protectionism was on the rise in the 1930s, we collect novel data and design empirical tests which show that retaliation against Smoot-Hawley was distinctive: it involved policies specifically directed at the U.S., the initial provocateur.

Using a new data set on quarterly bilateral trade flows as well as detailed information on who filed official protests during the legislative debate over the Tariff Act of 1930 and who (later) retaliated, gravity model estimates demonstrate that U.S. exports were severely affected by the Smoot-Hawley trade war. Even after controlling for financial crises, the effects of the global decline in aggregate demand, and the overall decline in partner countries' imports from all sources, U.S. exports fell substantially. If they had just fallen in line with the overall reduction in imports in each country, we would have found no effect: instead, they fell disproportionately, by between 15 and 33 percent, depending on the specification and the countries involved. By examining the effects for protestors as well as retaliators, we are able to more extensively assess the retaliation against Smoot-Hawley: this was not limited to those countries traditionally regarded as "retaliators".

Product-level regression estimates confirm that retaliators were strategic in their response to Smoot-Hawley (as they have been in more recent trade wars), choosing to bludgeon key U.S. exports differentially. Fast-growing U.S. exports of automobiles appear to have been particularly targeted by U.S. trade partners. Our results suggest that MFN constraints did not prevent countries from effectively retaliating. In addition to strategically targeted tariffs, retaliation involved such non-tariff measures as quotas, boycotts and increased sales resistance to American goods. Our results show that this retaliation was extremely effective in reducing U.S. exports. In March 2018, Peter Navarro famously predicted that no country would retaliate against U.S. tariffs. ${ }^{29}$ The evidence from the 1930s suggests it is a mistake, even for a country as wealthy and powerful as the United States, to assume that it can engage in a trade war with impunity.

\footnotetext{
${ }^{29} \mathrm{https}: / /$ twitter.com/MorningsMaria/status/969584638514679810?s=20.
} 


\section{References}

Adam, Marc Christopher. 2019. "Return of the Tariffs: The Interwar Trade Collapse Revisited" FU Berlin, School of Business and Economics Discussion paper.

Amiti, Mary, Sang Hoon Kong, and David Weinstein. 2020. "The Effect of the U.S.- China Trade War on U.S. Investment” NBER Working Paper 27114.

Amiti, Mary, Stephen J. Redding, and David Weinstein. 2019. “The Impact of the 2018 Tariffs on Prices and Welfare" Journal of Economic Perspectives, Vol. 33, No. 4, pp.187- 210.

Anderson, James E. and Eric van Wincoop. 2004. "Trade Costs" Journal of Economic Literature, Vol. 42, No. 3, pp.691-751.

Arkolakis, Costas, Svetlana Demidova, Peter Klenow and Andrés Rodriguez-Clare. 2008. "Endogenous Variety and the Gains from Trade" American Economic Review, Vol. 98, No. 2, pp.444-450.

Arkolakis, Costas, Arnaud Costinot and Andrés Rodriguez-Clare. 2012. "New Trade Models, Same Old Gains" American Economic Review, Vol. 102, No. 1, pp.94-130.

Arthi, Vellore, Markus Lampe, Ashwin R. Nair, and Kevin Hjortshøj O'Rourke. 2020. “The Impact of Interwar Protection: Evidence from India” NBER Working Paper 27178.

Bernanke, Ben S. and Harold James. 1991. "The Gold Standard, Deflation, and Financial Crisis in the Great Depression: An International Comparison" in R. Glenn Hubbard, Financial Markets and Financial Crises. Chicago: University of Chicago Press for NBER.

Bidwell, Percy W. 1930. "The New American Tariff: Europe's Answer” Foreign Affairs, Vol. 9, No. 1, pp.13-26.

Bond, Eric, Mario Crucini, Joel Rodrigue and Tristan Potter. 2013. "Misallocation and Productivity Effects of the Smoot-Hawley Tariff” Review of Economic Dynamics, Vol. 16(1), pp.120-134.

Callahan, Colleen M., Judith A. McDonald, and Anthony Patrick O'Brien. 1994. "Who Voted for Smoot-Hawley?" Journal of Economic History Vol. 54, No. 3, pp.683-90.

Clemens, Michael A., and Jeffrey G. Williamson. 2004. "Why Did the Tariff-Growth Correlation Change after 1950?” Journal of Economic Growth Vol. 9, No. 1, pp.5-46.

Conybeare, John A. C. 1987. Trade Wars: The Theory and Practice of International Commercial Rivalry. New York: Guildford: Columbia University Press.

Crucini, Mario. 1994. "Sources of Variation in Real Tariff Rates: The United States, 1900-1940" American Economic Review, Vol. 84, No. 3, pp.732-743. 
Crucini, Mario J. and James Kahn. 1996. "Tariffs and Aggregate Economic Activity: Lessons from the Great Depression" Journal of Monetary Economics, December, Vol. 38(3), pp.427-467.

Crucini, Mario J. and James Kahn. 2003. "Tariffs and the Great Depression Revisited" Staff Report No. 172, Federal Reserve Bank of New York.

Cupitt, Richard T., and Euel Elliott. 1994. "Schattschneider Revisited: Senate Voting on the Smoot-Hawley Tariff Act of 1930" Economics \& Politics Vol. 6, No. 3, pp.187-99.

De Bromhead, Alan, Alan Fernihough, Markus Lampe, and Kevin Hjortshøj O’Rourke. 2019. "When Britain Turned Inward: The Impact of Interwar British Protection" American Economic Review, Vol. 109, No. 2, pp.325-52.

Eaton, Jonathan and Samuel Kortum. 2002. "Technology, Geography, and Trade" Econometrica, Vol. 70, No. 5, pp.1741-1779.

Eichengreen, Barry. 1989. "The Political Economy of the Smoot-Hawley Tariff” Research in Economic History, pp.1-35.

Eichengreen, Barry and Douglas Irwin. 1995. "Trade Blocs, Currency Blocs and the Reorientation of World Trade in the 1930s" Journal of International Economics Vol. 38, pp.124.

Estevadeordal, Antoni, Brian Frantz and Alan M. Taylor. 2003. "The Rise and Fall of World Trade, 1870-1939” Quarterly Journal of Economics Vol. 118, No. 2, pp.359-407.

Fajgelbaum, Pablo D., Pinelopi K. Goldberg, Patrick J. Kennedy, and Amit K. Khandelwal. 2020. "The Return to Protectionism" Quarterly Journal of Economics Vol. 135, No. 1, pp.1-55.

Felbermayr, Gabriel, Benjamin Jung and Mario Larch. 2015. "The welfare consequences of import tariffs: A quantitative perspective" Journal of International Economics, Vol. 97 pp.295309.

Gowa, Joanne and Raymond Hicks. 2013. "Politics, Institutions, and Trade: Lessons of the Interwar Era” International Organization, Vol. 67, No. 03, pp. 439-67.

Grossman, Gene M. and Elhanan Helpman. 1994. "Endogenous Innovation in the Theory of Growth" Journal of Economic Perspectives, Vol.8, No.1, pp. 23-44.

Hayford, Marc and Carl Jr. Pasurka. 1992. "The Political Economy of the Fordney-McCumber and Smoot-Hawley Tariff Acts" Explorations in Economic History, Vol. 29, No.1, pp.30-50.

Head, Keith, Mayer, Thierry, \& John Ries. 2010. “The Erosion of Colonial Trade Linkages after Independence" Journal of International Economics, Vol. 81, No. 1, pp.1-14. 
Irwin, Douglas A. 1998a. "The Smoot-Hawley Tariff: A Quantitative Assessment" Review of Economics and Statistics Vol.80, No. 2, pp.326-34.

Irwin, Douglas A. 1998b. "From Smoot-Hawley to Reciprocal Trade Agreements: Changing the Course of U.S. Trade Policy in the 1930s" In The Defining Moment: The Great Depression and the American Economy in the Twentieth Century, edited by Michael D. Bordo, Claudia Goldin and Eugene N. White 325-52. Chicago: University of Chicago Press.

Irwin, Douglas A. 2011. Peddling Protectionism: Smoot-Hawley and the Great Depression. Princeton, N.J.; Oxford: Princeton University Press.

Irwin, Douglas A. 2017. Clashing over Commerce: A History of US Trade Policy, Markets and Governments in Economic History. Chicago, London: The University of Chicago Press.

Irwin, Douglas A., and Randall S. Kroszner. 1996. "Log-Rolling and Economic Interests in the Passage of the Smoot-Hawley Tariff" Carnegie-Rochester Conference Series on Public Policy Vol. 45, pp.173-200.

Jacks, David, Meissner, Chris, and Dennis Novy. 2008. “Trade Costs, 1870-2000” American Economic Review, Vol. 98, No. 2, pp. 529-34.

Jacks, David and Dennis Novy. 2019. "Trade Blocks and Trade Wars during the Interwar Period” CEPR Discussion Paper 13716.

James, Harold. 2001. The End of Globalization Lessons from the Great Depression, Harvard University Press Cambridge, MA.

Jones, Joseph M. 1934. Tariff Retaliation: Repercussions of the Hawley-Smoot Bill University of Pennsylvania Press, Philadelphia.

Kindleberger, Charles. 1973. "Commercial Policy Between the Wars" in Peter Mathias and Sidney Pollard (Eds.) The Cambridge Economic History of Europe from the Decline of the Roman Empire, pp.61-93.

Kitson, Michael and Solomos Solomou. 1990. Protectionism and Economic Revival: The British Interwar Economy, Cambridge: Cambridge University Press.

Kottman, Richard N. 1975. "Herbert Hoover and the Smoot-Hawley Tariff: Canada, A Case Study" Journal of American History, Vol. 62, No. 3, pp. 609-635.

League of Nations. various years. Memorandum on International Trade and the Balance of Payments and International Trade Statistics. Geneva: League of Nations.

Madsen, Jacob, B. 2001. "Trade Barriers and the Collapse of World Trade during the Great Depression” Southern Economic Journal Vol. 67, No. 4, pp.848-868. 
Mann, Catherine L. 1987. "Protection and Retaliation: Changing the 'Rules of the Game"' Brookings Papers on Economic Activity, Vol. 1987, No. 1, pp.311-335.

Mann, Lawrence B. 1930. "Foreign Reactions to the American Tariff Act" Foreign Policy Reports, Foreign Policy Association, pp.261-78.

Mann, Thomas C. 1958. "American Trade Policy and the Lessons of the 1930s" Department of State Bulletin, Vol. 38, No. 98, pp.895-8.

McDonald, Judith A., Anthony Patrick O’Brien, and Colleen M. Callahan. 1997. "Trade Wars: Canada 's Reaction to the Smoot-Hawley Tariff' Journal of Economic History, Vol. 57, No. 4, pp.802-26.

Obstfeld, Maurice, Jay C. Shambaugh and Alan Taylor. 2004. Monetary, "Sovereignty, Exchange Rates and Capital Controls: the Trilemma in the Interwar Period" IMF Staff Papers, Vol. 51, IMF Fourth Annual Research Conference, pp.75-108.

O’Rourke, Kevin. 1991. "Burn Everything British but Their Coal: The Anglo-Irish Economic War of the 1930s" Journal of Economic History, Vol. 51, No. 2, pp.357-366.

Pastor, Robert A. 1980. Congress and the Politics of U.S. Foreign Economic Policy, 1929-1976. Berkeley, California: University of California Press.

Ritschl, Albrecht and Nikolaus Wolf. 2011. "Endogeneity of Currency Areas and Trade Blocs: Evidence from a Natural Experiment" Kyklos, Vol 64, No. 2, pp.291-312.

Santos Silva, J. M. C. and Silvana Tenreyro. 2006. "The Log of Gravity" Review of Economics and Statistics, Vol. 88, No. 4, pp. 641-658. 
Table 1. Ten largest U.S. trade partners in 1928

\begin{tabular}{|c|c|c|c|c|c|}
\hline \multicolumn{3}{|c|}{ U.S. Exports to } & \multicolumn{3}{|c|}{ U.S. Imports from } \\
\hline Trade Partner & $\begin{array}{l}\text { Total Exports } \\
\text { (\$ Millions) }\end{array}$ & $\begin{array}{c}\text { Percent of } \\
\text { Total } \\
\text { Exports }\end{array}$ & Trade Partner & $\begin{array}{r}\text { Total Imports } \\
\text { (\$ Millions) }\end{array}$ & $\begin{array}{c}\text { Percent of } \\
\text { Total } \\
\text { Imports }\end{array}$ \\
\hline Great Britain & 917.8 & 18.1 & Canada & 440.3 & 11.7 \\
\hline Canada & 811.9 & 16.0 & Japan & 351.6 & 9.3 \\
\hline Germany & 483.2 & 9.5 & Great Britain & 303.1 & 8.0 \\
\hline Japan & 265.0 & 5.2 & $\begin{array}{l}\text { British } \\
\text { Indies }\end{array}$ & 234.1 & 6.2 \\
\hline France & 216.9 & 4.3 & Germany & 211.5 & 5.6 \\
\hline Italy & 184.4 & 3.6 & Brazil & 202.9 & 5.4 \\
\hline Argentina & 175.0 & 3.4 & Mexico & 198.5 & 5.3 \\
\hline $\begin{array}{l}\text { Australia \& } \\
\text { New Zealand }\end{array}$ & 164.5 & 3.2 & Cuba & 187.0 & 5.0 \\
\hline Cuba & 127.6 & 2.5 & India & 158.3 & 4.2 \\
\hline Netherlands & 127.0 & 1.2 & France & 127.7 & 3.4 \\
\hline
\end{tabular}

Source: Authors' calculations based on domestic country sources. See appendix A. Bold indicates that a country retaliated, italics indicates that a country petitioned, countries in bold and italics petitioned and retaliated. 


\section{Table 2. Protesters, Retaliators, and U.S. Imports after Smoot-Hawley}

$\begin{array}{ccc}\begin{array}{c}\text { Percentage Change } \\ \text { in U.S. Imports }\end{array} & \begin{array}{c}\text { Protester (date of } \\ \text { first }\end{array} & \text { Retaliator } \\ (\underline{4 / 1929-4 / 1932)} & \underline{\text { correspondence) }}\end{array}$

\section{Country}

Ireland

Argentina

Uruguay

Latvia

Great Britain

India

Germany

Austria

Australia and New Zealand

Canada

Spain

Czechoslovakia

Mexico

Japan

British West Indies

Netherlands

France

Greece

Cuba

Italy

Iran, Iraq and Afghanistan

Denmark

Dominican Republic

Turkey

Belgium and Luxembourg

Switzerland

Sweden

Portugal

Finland

Honduras

Guatemala

Norway

Romania
$-92.3$

$-82.3$

$-79.3$

$-72.0$

$-71.3$

$-69.5$

$-68.3$

$-67.3$

$-67.1$

$-60.1$

$-57.4$

$-54.2$

$-53.8$

$-52.8$

$-52.0$

$-51.8$

$-47.7$

$-47.1$

$-45.9$

$-45.5$

$-44.5$

$-43.4$

$-37.0$

$-33.5$

$-29.5$

$-20.2$

$-15.7$

$-15.5$

$-5.7$

$-2.0$

11.6

25.6

119.3

$\begin{array}{cc}8 / 20 / 1929 & \mathrm{X} \\ 6 / 8 / 1929 & \mathrm{X}\end{array}$

7/30/1929

2/26/1929

$6 / 29 / 1929$

$8 / 15 / 1929$

6/8/1929

6/28/1929

$3 / 15 / 1929$

4/26/1929

7/5/1929

6/20/1929

X

$7 / 25 / 1929$

$6 / 22 / 1929$

6/12/1929

$5 / 21 / 1929$

X

6/19/1929

5/27/1929

X

3/12/1929

5/14/1929

4/15/1929

$6 / 18 / 1929$

$5 / 24 / 1929$

6/10/1929

X

7/1/1929

8/3/1929

7/23/1929

$3 / 23 / 1929$

3/9/1929

$6 / 1 / 1929$

$6 / 27 / 1929$

Note: Protesters filed petitions with the U.S. State Department. Retaliators imposed tariffs in response to SmootHawley as per Mann (1930) and Jones (1934). Threateners are the subset of protesters who were not retaliators. 
Table 3. Predicting who Responded to Smoot-Hawley

\begin{tabular}{|c|c|c|c|c|}
\hline Independent Variable & & & & \\
\hline $\begin{array}{l}\text { Exports to the U.S. as } \\
\text { share of total exports }\end{array}$ & $\begin{array}{l}2.122 * \\
(1.273)\end{array}$ & & & $\begin{array}{c}1.903 \\
(1.921)\end{array}$ \\
\hline $\begin{array}{l}\text { Trade Balance as share of } \\
\text { total trade }\end{array}$ & & $\begin{array}{c}3.436^{* * *} \\
(1.221)\end{array}$ & & $\begin{array}{r}4.085^{* *} \\
(1.863)\end{array}$ \\
\hline $\begin{array}{l}\text { Trade Balance versus } \\
\text { U.S. as share of total } \\
\text { trade }\end{array}$ & & & $\begin{array}{l}3.048^{*} \\
(1.557)\end{array}$ & $\begin{array}{l}-2.624 \\
(3.363)\end{array}$ \\
\hline $\begin{array}{l}\text { Most Favored Nation } \\
\text { Clause }\end{array}$ & $\begin{array}{c}0.325 \\
(0.513)\end{array}$ & $\begin{array}{l}-0.074 \\
(0.528)\end{array}$ & $\begin{array}{c}0.360 \\
(0.484)\end{array}$ & $\begin{array}{l}-0.017 \\
(0.549)\end{array}$ \\
\hline Polity Score & $\begin{array}{l}0.139 * * * \\
(0.0395)\end{array}$ & $\begin{array}{c}0.141 * * * \\
(0.044)\end{array}$ & $\begin{array}{c}0.131 * * * \\
(0.041)\end{array}$ & $\begin{array}{c}0.145^{* * *} \\
(0.040)\end{array}$ \\
\hline Indebtedness Dummy & $\begin{array}{l}-0.404 \\
(0.664)\end{array}$ & $\begin{array}{l}-0.375 \\
(0.792)\end{array}$ & $\begin{array}{l}-0.522 \\
(0.715)\end{array}$ & $\begin{array}{l}-0.297 \\
(0.777)\end{array}$ \\
\hline Continent Dummies & YES & YES & YES & YES \\
\hline Pseudo R2 & 0.3401 & 0.4132 & 0.3397 & 0.4222 \\
\hline Observations & 44 & 44 & 43 & 43 \\
\hline
\end{tabular}

Notes: The dependent variable takes on a value of 1 when an economy filed a formal complaint with the U.S. State Department during the debate on Smoot-Hawley or when countries imposed retaliatory tariffs in response to the passage of Smoot-Hawley. Regression estimates based on probit analysis. Robust standard errors are shown in parentheses. ${ }^{* *} \mathrm{p}<0.01,{ }^{* *} \mathrm{p}<0.05,{ }^{*} \mathrm{p}<0.1$ 
Table 4. The Effects of Retaliation on Imports

(Dependent Variable: (Log) Bilateral Imports)

\begin{tabular}{|c|c|c|c|c|}
\hline & & Estima & on Procedur & \\
\hline & OLS & PPML & OLS & PPML \\
\hline Independent Variable & & & & \\
\hline Responder & $-0.287 * * *$ & $-0.194 * * *$ & & \\
\hline & $(0.102)$ & $(0.061)$ & & \\
\hline Retaliator & & & $-0.396 * * *$ & $-0.333 * * *$ \\
\hline & & & $(0.109)$ & $(0.084)$ \\
\hline Threatener & & & $-0.248 * *$ & $-0.157 * *$ \\
\hline & & & $(0.113)$ & $(0.064)$ \\
\hline Constant & $12.65 * * *$ & $16.68 * * *$ & $12.65 * * *$ & $16.68 * * *$ \\
\hline & $(0.005)$ & $(0.008)$ & $(0.005)$ & $(0.008)$ \\
\hline Pairwise, time-varying control variables & YES & YES & YES & YES \\
\hline Observations & 96,101 & 105,923 & 96,101 & 105,923 \\
\hline (Pseudo) R-squared & 0.918 & & 0.918 & \\
\hline
\end{tabular}

Notes: All regressions include exporter-time, importer-time, and pair fixed effects, as well as pairwise, time-varying controls for membership of the sterling, Reichsmark and gold blocs and the British imperial preference system; the Anglo-Irish trade war; RTAA agreements with the United States; and simultaneous financial crises. In the OLS specifications, bilateral imports are measured in logs. Standard errors are clustered at the country-product level and shown in parentheses. *** $\mathrm{p}<0.01, * * \mathrm{p}<0.05, * \mathrm{p}<0.1$ 
Table 5. Robustness Checks - The Effects of Retaliation on Imports - Sovereign Countries (Dependent Variable: (Log) Bilateral Imports)

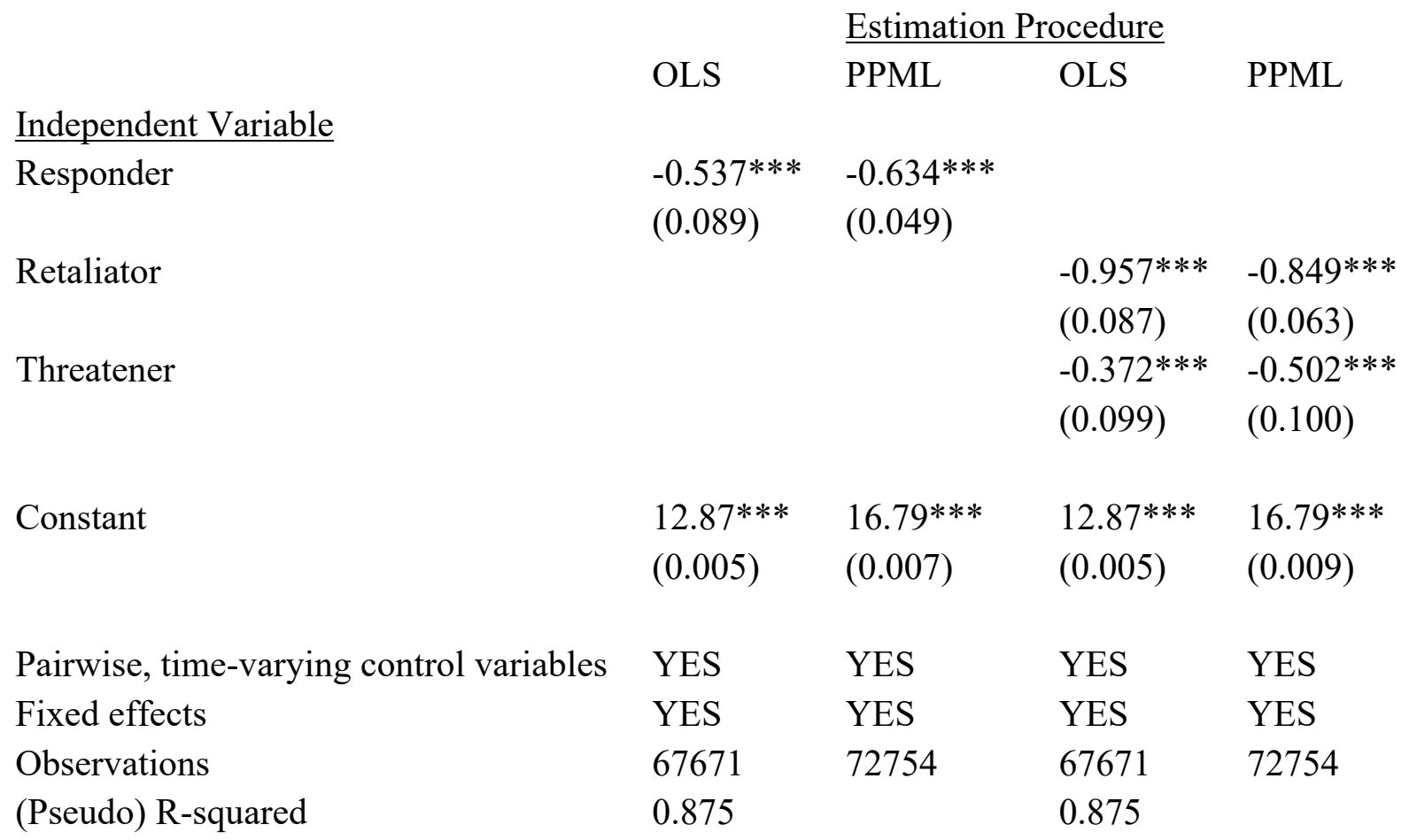

Notes: All regressions include exporter-time, importer-time, and pair fixed effects, as well as pairwise, time-varying controls for membership of the sterling, Reichsmark and gold blocs and the British imperial preference system; the Anglo-Irish trade war; RTAA agreements with the United States; and simultaneous financial crises. In the OLS specifications, bilateral imports are measured in logs. Standard errors are clustered at the country-product level and shown in parentheses. $* * *$ $\mathrm{p}<0.01,{ }^{* *} \mathrm{p}<0.05,{ }^{*} \mathrm{p}<0.1$ 


\section{Table 6. Dropping Individual Retaliators from the Sample}

(Dependent Variable: (Log) Bilateral Imports)

\begin{tabular}{|c|c|c|c|}
\hline \multirow[b]{2}{*}{ Omitted Country } & \multirow[b]{2}{*}{$\begin{array}{l}\text { Independent } \\
\text { Variable }\end{array}$} & \multicolumn{2}{|c|}{ Estimation Procedure } \\
\hline & & $\underline{\text { OLS }}$ & $\underline{\text { PPML }}$ \\
\hline Canada & Retaliator & $\begin{array}{l}-0.483 * * * \\
(0.12)\end{array}$ & $\begin{array}{l}-0.384 * * * \\
(0.11)\end{array}$ \\
\hline France & Retaliator & $\begin{array}{l}-0.428 * * * \\
(0.11)\end{array}$ & $\begin{array}{l}-0.411 * * * \\
(0.09)\end{array}$ \\
\hline Italy & Retaliator & $\begin{array}{l}-0.416^{* * *} \\
(0.11)\end{array}$ & $\begin{array}{l}-0.340 * * * \\
(0.09)\end{array}$ \\
\hline Spain & Retaliator & $\begin{array}{l}-0.397 * * * \\
(0.11)\end{array}$ & $\begin{array}{l}-0.340 * * * \\
(0.09)\end{array}$ \\
\hline Switzerland & Retaliator & $\begin{array}{l}-0.420 * * * \\
(0.12)\end{array}$ & $\begin{array}{l}-0.343 * * * \\
(0.09)\end{array}$ \\
\hline Argentina & Retaliator & $\begin{array}{l}-0.373^{* * *} \\
(0.11)\end{array}$ & $\begin{array}{l}-0.327 * * * \\
(0.09)\end{array}$ \\
\hline Mexico & Retaliator & $\begin{array}{l}-0.377 * * * \\
(0.11)\end{array}$ & $\begin{array}{l}-0.338 * * * \\
(0.09)\end{array}$ \\
\hline Cuba & Retaliator & $\begin{array}{l}-0.426^{* * *} \\
(0.11)\end{array}$ & $\begin{array}{l}-0.343 * * * \\
(0.09)\end{array}$ \\
\hline $\begin{array}{l}\text { Australia \& } \\
\text { New Zealand }\end{array}$ & Retaliator & $\begin{array}{l}-0.362^{* * *} \\
(0.11)\end{array}$ & $\begin{array}{l}-0.270 * * * \\
(0.07)\end{array}$ \\
\hline $\begin{array}{l}\text { Uruguay \& } \\
\text { Paraguay }\end{array}$ & Retaliator & $\begin{array}{l}-0.384 * * * \\
(0.11)\end{array}$ & $\begin{array}{l}-0.327 * * * \\
(0.08)\end{array}$ \\
\hline $\begin{array}{l}\text { Argentina, Uruguay, } \\
\& \text { Paraguay combined }\end{array}$ & Retaliator & $\begin{array}{l}-0.332 * * * \\
(0.11)\end{array}$ & $\begin{array}{l}-0.287 * * * \\
(0.08)\end{array}$ \\
\hline
\end{tabular}

Notes: Regression estimates and extended note are as in Table 4, with the exception of the "omitted country," which is dropped from the sample in the estimation. See text for details. Results for additional U.S. trade partners are available from the authors. ${ }^{* * *} \mathrm{p}<0.01,{ }^{* *} \mathrm{p}<0.05,{ }^{*} \mathrm{p}<0.1$ 


\section{Table 7. Robustness Checks - Differentiating the Retaliators}

(Dependent Variable: (Log) Bilateral Imports)

\section{Estimation Procedure}

$\begin{array}{lll}\text { Independent Variable } & \text { OLS } & \text { PPML } \\ \text { Retaliators with Imperial Preferences } & -0.549^{* * *} & -0.553^{* * *} \\ & (0.202) & (0.145) \\ \text { Retaliators in Gold Bloc } & -0.260^{* *} & -0.210^{* *} \\ & (0.113) & (0.083) \\ \text { Remaining Retaliators } & -0.452^{* * *} & -0.364^{* * *} \\ & (0.132) & (0.081) \\ \text { Threatener } & -0.252^{* *} & -0.156^{* *} \\ & (0.114) & (0.062) \\ \text { Constant } & 12.65^{* * *} & 16.70^{* * *} \\ & (0.005) & (0.007) \\ & & \\ \text { Pairwise, time-varying control variables } & \text { YES } & \text { YES } \\ \text { Fixed effects } & \text { YES } & \text { YES } \\ \text { Observations } & 96101 & 105923 \\ \text { (Pseudo) R-squared } & 0.918 & \end{array}$

Notes: All regressions include exporter-time, importer-time, and pair fixed effects, as well as pairwise, time-varying controls for membership of the sterling and Reichsmark blocs; the AngloIrish trade war; RTAA agreements with the United States; and simultaneous financial crises. In the OLS specifications, bilateral imports are measured in logs. Standard errors are clustered at the country-product level and shown in parentheses. ${ }^{* * *} \mathrm{p}<0.01, * * \mathrm{p}<0.05,{ }^{*} \mathrm{p}<0.1$ 
Table 8. The Effects of Retaliation on Product Level U.S. Exports

(Dependent Variable: (Log) Bilateral Exports)

\section{$\underline{\text { Panel } A}$}

$\underline{\text { Independent Variable }}$

Constant

Responder*Top 10

Retaliator*Top 10

Threatener*Top 10

Pseudo R-squared

\section{Panel B}

Constant

Responder*Top 10

Responder*Top10*Automobile

Retaliator*Top 10

Retaliator*Top10*Automobile

Threatener*Top 10

Threatener*Top10*Automobile

\author{
$\underline{\text { Coefficient Estimate }}$
}

$14.28 * * * \quad 14.29 * * *$

(0.00)

(0.000)

$-0.255^{* * *}$

(0.000)

$$
-0.396 * * *
$$

$-0.224 * * *$

(0.068)

0.94

0.94
$14.28 * * *$
(0.018)
$-0.219 * * *$
(0.066)
$-0.303 *$
(0.158)

$14.28 * * *$

(0.018)

$-0.315 * *$

(0.125)

$-0.613 * * *$

(0.262)

$-0.191 * *$

(0.064)

$-0.279 *$

(0.144)

Pseudo R-squared

0.94

0.94

21,361

Notes: See variable definitions in the text. All regressions are estimated using PPML and include country*time, good*time, and good*country fixed effects. Standard errors are clustered at the country-product level and shown in parentheses. $* * * \mathrm{p}<0.01, * * \mathrm{p}<0.05, * \mathrm{p}<0.1$. 
Table 9. Welfare Impact of Smoot-Hawley Trade War

Average change in welfare for different groups: $\delta \eta=0$

\begin{tabular}{|c|c|c|c|c|}
\hline & \multicolumn{2}{|c|}{$\frac{\text { Change in Welfare }}{\text { (percentage points) }}$} & \multicolumn{2}{|c|}{$\frac{\text { Percentage Change in }}{\text { Welfare from: }}$} \\
\hline & 1929 to 1930 & 1929 to 1931 & 1929 to 1930 & 1929 to 1931 \\
\hline Threateners (15) & 0.232 & 0.138 & $3.1 \%$ & $3.4 \%$ \\
\hline Retaliators (7) & -0.280 & -0.559 & $-8.5 \%$ & $-17.6 \%$ \\
\hline US & 0.067 & -0.103 & $9.2 \%$ & $-14.2 \%$ \\
\hline
\end{tabular}

Average change in welfare for different groups: $\delta \eta=0.65$

\begin{tabular}{|c|c|c|c|c|}
\hline & \multicolumn{2}{|c|}{$\frac{\text { Change in Welfare }}{\text { (percentage points) }}$} & \multicolumn{2}{|c|}{$\frac{\text { Percentage Change in }}{\text { Welfare from: }}$} \\
\hline & 1929 to 1930 & 1929 to 1931 & 1929 to 1930 & 1929 to 1931 \\
\hline Threateners (15) & 0.267 & 0.197 & $3.3 \%$ & $4.5 \%$ \\
\hline Retaliators (7) & -0.310 & -0.604 & $-8.4 \%$ & $-17.1 \%$ \\
\hline US & 0.075 & -0.114 & $9.4 \%$ & $-14.2 \%$ \\
\hline
\end{tabular}

Notes: Calculations are based on the methods outlined in Felbermayr et al. (JIE, 2015). 
Figure 1. U.S. Exports and Imports before and after passage of Smoot-Hawley

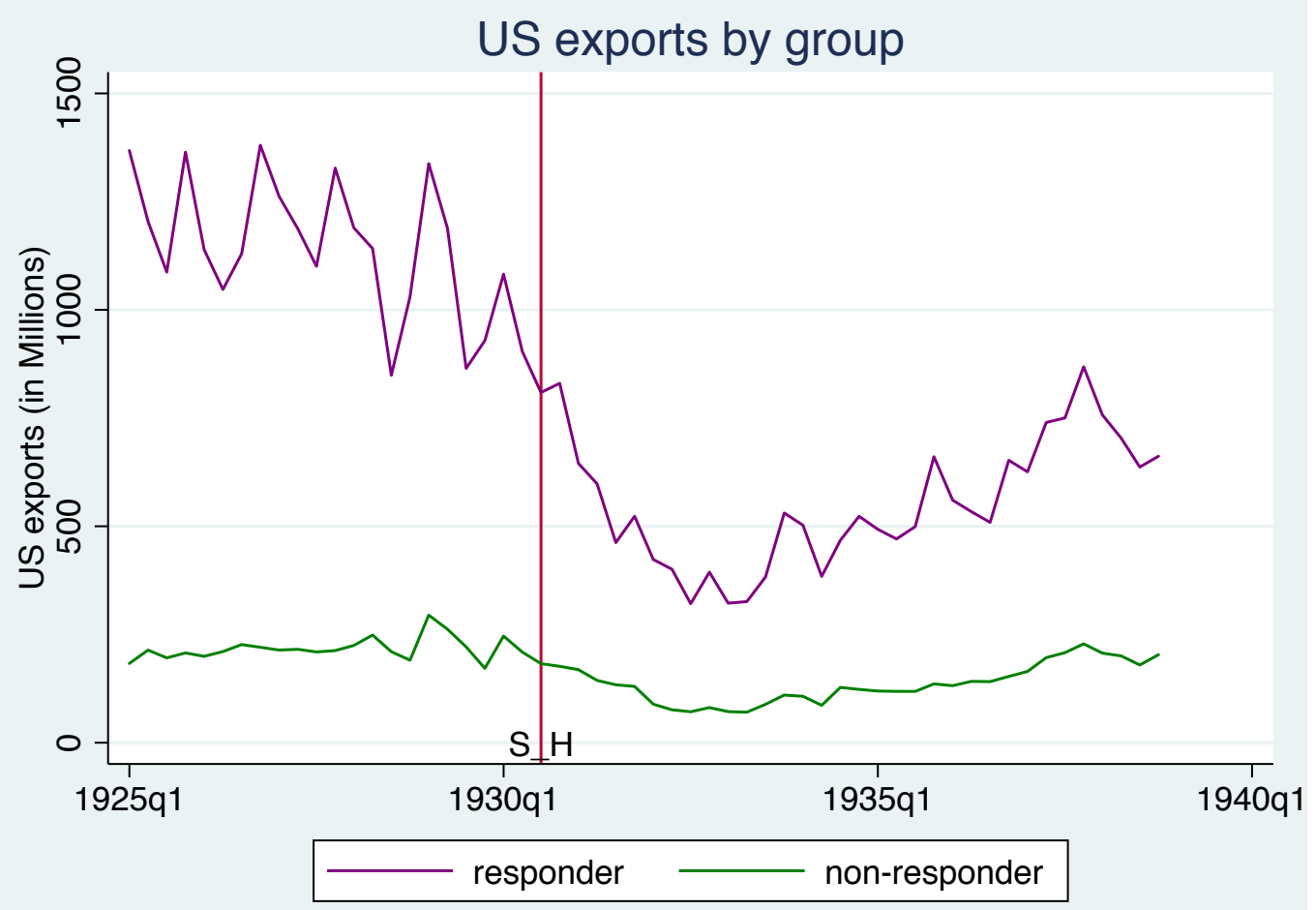

$\mathbf{S}$

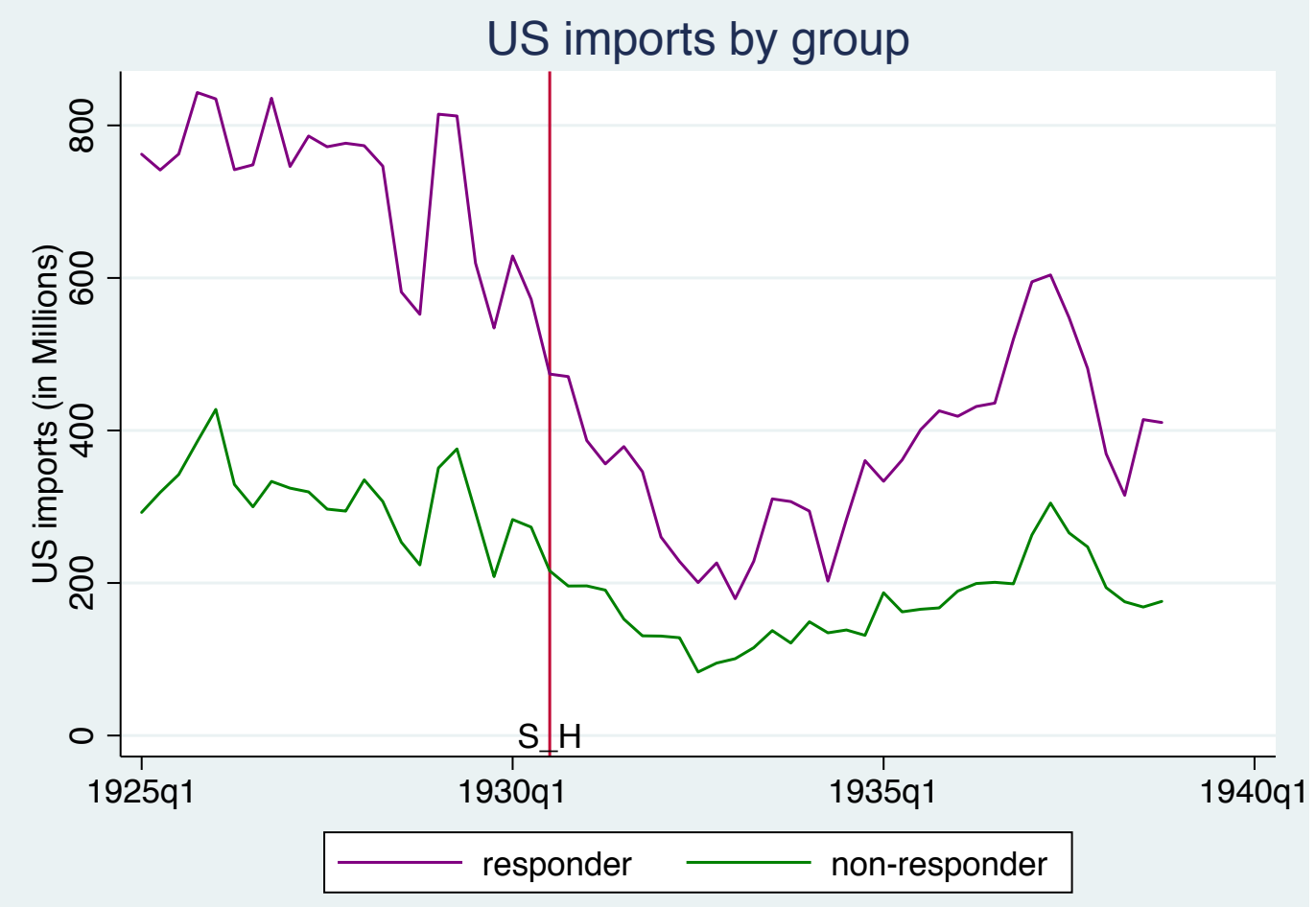


Figure 2. Imports from the U.S. before and after Smoot-Hawley

\section{Retaliator Imports from the US (million USD)}
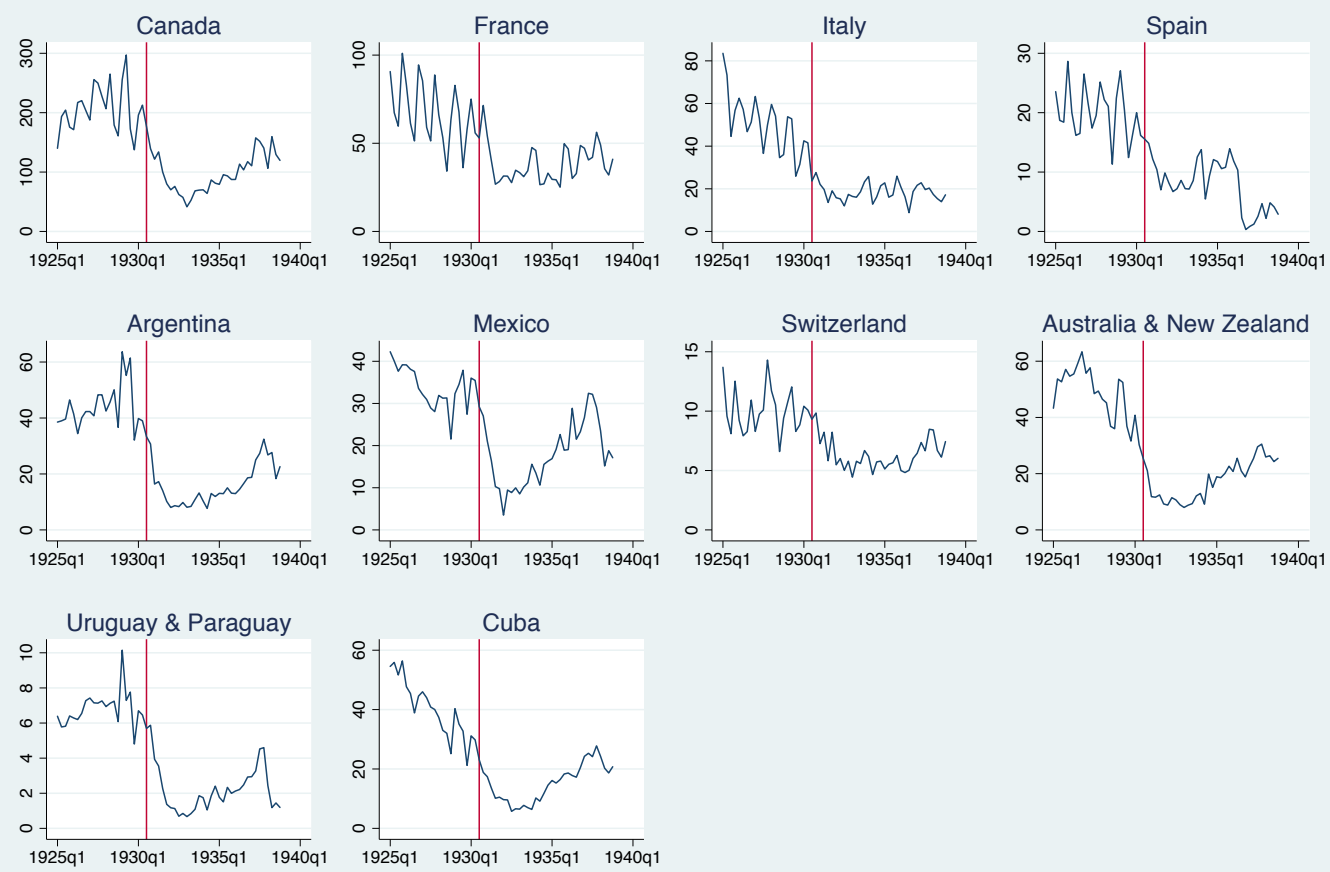

\section{Threatener Imports from the US (million USD)}
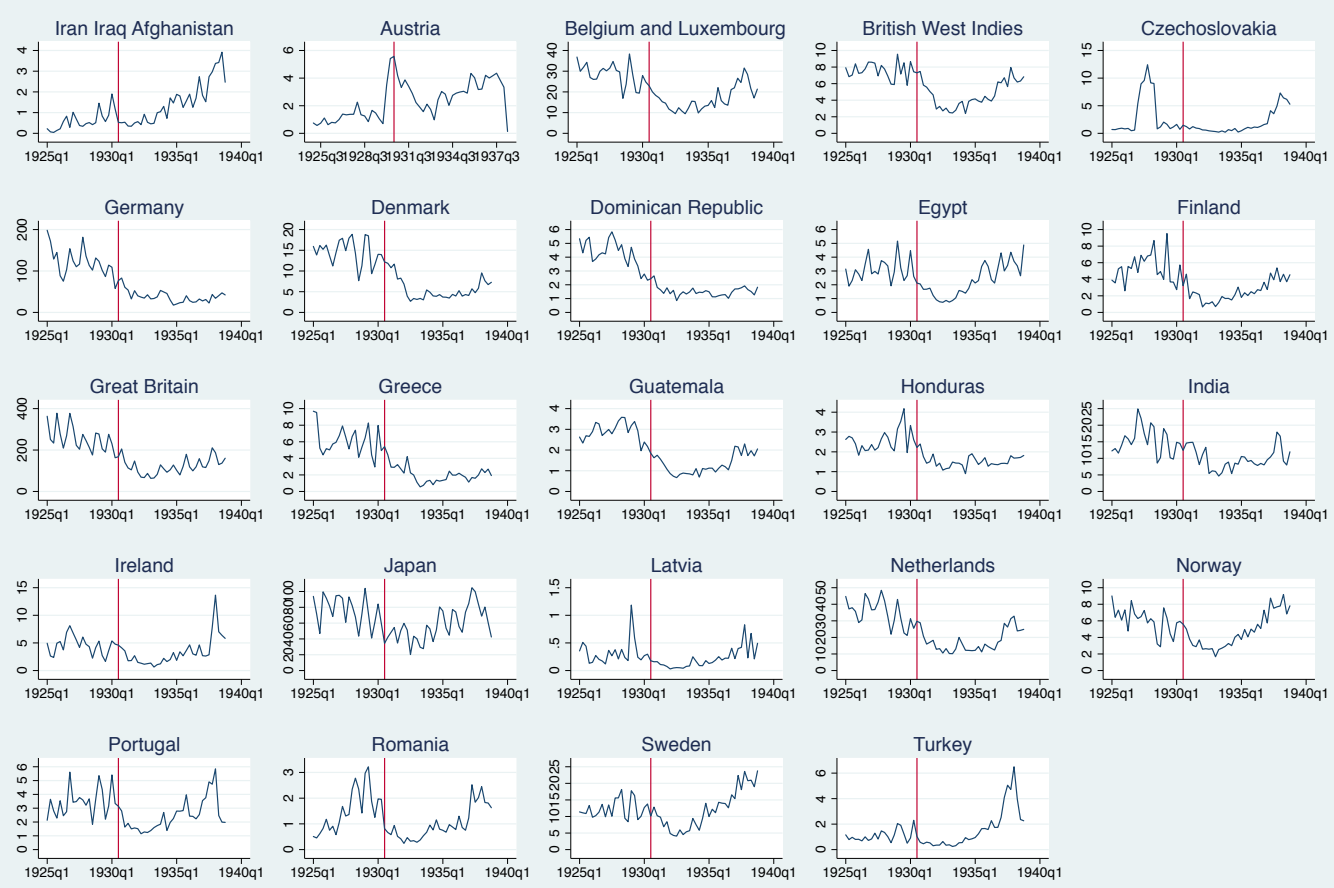


\section{Appendix A: Trade Data from Country Sources}

Austria: Statistik das Aussenhandles

February 1930 through January 1939, monthly

Belgium: Comptes Speciaux par Pays de Provence et de Destination: Part 1

Brazil: Foreign Trade

1932-1939, quarterly

Bulgaria: Bulletin Statistique Mensuel

June 1920 through December 1939, monthly

Canada: Monthly Report of the Trade of Canada: Imports for Consumption and Exports. Canada, Dominion Bureau of Statistics

January 1929 through December 1939, monthly

Czechoslovakia: Monthly Summary of Foreign Trade

April 1924 through June 1939, monthly

Denmark: Handelsstatistiske Meddelelser

January 1927 through December 1940, monthly

Egypt: Foreign Trade

January 1919 through September 1940, monthly

Estonia: Eesti Statistika

January 1923 through December 1937, monthly

Finland: Ulkomaankauppa Utrikes Handel, Commerce Extérieur de la Finlande, Finland, Tilastokeskus, Helsinki.

January 1921 through August 1939, monthly

France: Statistique Mensuelle du Commerce Exterieur de la France, January 1919- December 1938, monthly

Germany: Monatliche Nachweise über den auswärtigen Handel Deutschlands, 1924 through Quarter 1 1937, quarterly; March 1937 through October 1939, monthly. 
Great Britain: Accounts Relating to Trade and Navigation of the United Kingdom. January 1920-July 1939, monthly. Sir Auckland Geddes, ordered by The House of Commons, London: Published by his majesty's stationary office.

Greece: Bulletin Mensuel du Commerce Special January 1925 through August 1940, monthly

Hong Kong: Trade and Shipping Returns

April 1930 through December 1940, monthly

Hungary: Statisztikai Havi Kozlemenyek

1925 through 1936, quarterly.

Iceland: Statistical Yearbook

July 1934 - December 1934 and May 1935 - November 1941, monthly.

India: Trade and Navigation

January 1922 through December 1940, monthly

Ireland: Trade and Shipping Returns

Italy: Movimento Commerciale del Regno D'Italia, Ministero dello Finanze, Officion Trattati e Lebislazione Doganale, (1919-1935years?)

Japan: Monthly Return of the Foreign Trade of the Empire of Japan

Latvia: Commerce et Transit

1929 through 1938, monthly

Lithuania: Bulletin Statistique

November 1923 through August 1939, monthly

Malaya: Imports and Exports

July 1921 through December 1936, monthly

Mexico: Commercio Exterior Y Navegacion, January 1928- December 1929 and Revista de Economia Y Edstadistica, April 1932-Februrary 1940, monthly.

Netherlands: Handelsverkeer

Quarter 1 1934-Quarter 3 1939, quarterly 
Norway: Statistiske Meddelelser

Quarter 11932 through October 1939, quarterly

Palestine: Commercial Bulletin

July 1924 through October 1939, monthly

Poland: Handel z Poszczególnemi Krajami

January 1925 through May 1939, monthly starting in January 1927

Romania: Commerce Exterieur

October-December 1935 and April 1937 - January 1939, monthly

Sierra Leone: Royal Gazette Trade Supplement

January 1931 through January 1940, monthly.

South Africa: Monthly Trade

Dates: 1919 through 1934, quarterly

Switzerland: Statistique Mensuelle du Commerce Exterieur

January 1925 through December 1940, monthly

Sweden: Commersiella Meddelanden

January 1933 - September 1939, monthly

Turkey: Commerce Exterieur

1934 through 1939 , monthly

United States: Monthly Summary of the Foreign Commerce of the United States January 1917 through September 1941, monthly 
Appendix B: Grouping of Countries for the Analysis

\begin{tabular}{|c|c|}
\hline Aggregate used in Estimation & Countries/Regions included \\
\hline ARABIA & $\begin{array}{l}\text { Bahrein, British Arabia, Hadramout, Hedjaz, Hejaz } \\
\text { Arabia and Mesopotamia, Hejaz-Nejd, Kuwait, } \\
\text { Muscat Territory and Trucial Oman, Muscat Oman } \\
\text { Trucial Oman and Kuwait, Oman, Saudi Arabia, Saudi } \\
\text { Arabia and Yemen, Socotora, Yemen }\end{array}$ \\
\hline $\begin{array}{l}\text { ASCENSION FALKLANDS } \\
\text { ST.HELENA }\end{array}$ & $\begin{array}{l}\text { Ascension, Ascension and St Helena, Falklands, St } \\
\text { Helena, Tristan da Cunha }\end{array}$ \\
\hline BELGIAN AFRICA & $\begin{array}{l}\text { Belgian Colonies, Belgian Congo, Congo, Ruanda and } \\
\text { Burundi, Rwanda }\end{array}$ \\
\hline BELGIUM AND LUXEMBURG & Belgium, Luxemburg \\
\hline BHUTAN AND NEPAL & Bhutan, Nepal \\
\hline BRITISH EAST AFRICA & $\begin{array}{l}\text { British East and West Equatorial Africa, British East } \\
\text { Equatorial Africa, British Somaliland, Kenya, Kenya } \\
\text { and Uganda, Kenya Uganda and Tanganyika, } \\
\text { Tanganyika, Uganda, Zanzibar, Zanzibar and Pemba }\end{array}$ \\
\hline BRITISH EAST INDIES & $\begin{array}{l}\text { British Borneo, British Malacca, British Malaya, } \\
\text { British North Borneo, Brunei, Federated Malay States, } \\
\text { Malakka, Malay States, Malaysia, North Borneo, other } \\
\text { British East Indies, Sarawak, Singapore, Straits and } \\
\text { FMS, Straits Settlements, Straits Settlements and } \\
\text { Labuan, unfederated Malay States }\end{array}$ \\
\hline BRITISH MEDITERRANEAN & $\begin{array}{l}\text { Cyprus, Gibraltar, Gibraltar et Malta, Malta, Malta } \\
\text { and Gozo, Malta Gozo and Cyprus }\end{array}$ \\
\hline BRITISH OCEANIA & $\begin{array}{l}\text { Australasia, Australia, Australia and New Zealand, } \\
\text { Australia Oceania, British Solomon Islands, Cook } \\
\text { Islands, Fiji, Gilberte and Ellice Islands, Nauru, Nauru } \\
\text { and British Samoa, Nauru and Western Samoa, New } \\
\text { Guinea, New Hebrides, New Zealand, New Zealand } \\
\text { and Oceania, other Australia, other British Oceania, } \\
\text { other islands in the Pacific (British), Papua, Papua } \\
\text { New Guinea, Ross Dependency, Samoa, Tonga }\end{array}$ \\
\hline BRITISH SOUTHERN AFRICA & $\begin{array}{l}\text { North Eastern Rhodesia, North West Rhodesia, } \\
\text { Northern Rhodesia, Northern Rhodesia/Congo Basin, } \\
\text { Nyasaland, other British South Africa, Rhodesia, } \\
\text { Southern Rhodesia }\end{array}$ \\
\hline BRITISH SUDAN & Anglo-Egyptian Sudan, Sudan \\
\hline BRITISH WEST AFRICA & $\begin{array}{l}\text { British Cameroon, British Togo, British West } \\
\text { Equatorial Africa, Gambia, Gold Coast, Gold Coast } \\
\text { and British Togoland, Nigeria, Nigeria and British } \\
\text { Cameroon, other British West Africa, Sierra Leone }\end{array}$ \\
\hline BRITISH WEST INDIES & $\begin{array}{l}\text { Antigua, Antilles and British Guiana, Bahamas, } \\
\text { Barbados, Bermuda, British Antilles, British Guiana, } \\
\text { British Honduras, Cayman Islands, Grenada, Guiana, }\end{array}$ \\
\hline
\end{tabular}




\begin{tabular}{|c|c|}
\hline & $\begin{array}{l}\text { Jamaica, Jamaica and Antilles, Leeward Islands, other } \\
\text { British Caribbean, other British West Indies, St } \\
\text { Christopher, St Lucia, St Vincent, Trinidad, Trinidad } \\
\text { and Tobago, Union Island, Winward Islands }\end{array}$ \\
\hline CHINA & China and Manchuria, other China \\
\hline COLOMBIA & Colombia and Galapagos \\
\hline DOMINICAN REPUBLIC & San Domingo \\
\hline DUTCH EAST INDIES & $\begin{array}{l}\text { Borneo and Java, Dutch Borneo, Dutch India, Dutch } \\
\text { New Guinea, Java and Madura, other Dutch East } \\
\text { Indies, other Dutch possessions in the Indian Seas }\end{array}$ \\
\hline DUTCH WEST INDIES & Curacao, Dutch Antilles, Dutch Guiana \\
\hline FRANCE & Alsace Lorraine \\
\hline FRENCH EAST AFRICA & French Somali Coast \\
\hline FRENCH EAST INDIES & $\begin{array}{l}\text { Cochin China, French India, French Indochina, Indo- } \\
\text { china }\end{array}$ \\
\hline FRENCH NORTH AFRICA & $\begin{array}{l}\text { Algeria, Algeria and Tunis, French Morocco, } \\
\text { French Morocco and Tanger, Morocco, Tunis, Tunisia }\end{array}$ \\
\hline FRENCH OCEANIA & New Caledonia, Society Islands \\
\hline FRENCH WEST AFRICA & $\begin{array}{l}\text { Cote d'Ivoire, Dahomey, Dakar, French Cameroon, } \\
\text { French Congo, French Equatorial Africa, French } \\
\text { Guinea, French Niger, French Sudan, French Togo, } \\
\text { French West and Equatorial Africa, French West } \\
\text { Equatorial Africa, Mauritania, other French West } \\
\text { Africa, Senegal, Togo, Upper Volta }\end{array}$ \\
\hline FRENCH WEST INDIES & $\begin{array}{l}\text { French Antilles, French Guiana, Guadeloupe, } \\
\text { Martinique }\end{array}$ \\
\hline GERMANY & North Sea Free Ports \\
\hline INDIA & $\begin{array}{l}\text { Aden, British India and Burma, British India and } \\
\text { Ceylon, Burma, Ceylon, other British India }\end{array}$ \\
\hline IRAN IRAQ AND AFGHANISTAN & $\begin{array}{l}\text { Afghanistan, Iran, Iran and Afghanistan, Iraq, Iraq and } \\
\text { Afghanistan, Mesopotamia, Persia Mesopotamia } \\
\text { Afghanistan }\end{array}$ \\
\hline ITALIAN AFRICA & $\begin{array}{l}\text { Cyrenaica, Eritrea, Eritrea and Italian Somali Coast, } \\
\text { Italian East Africa, Italian Somaliland, Libya, other } \\
\text { Italian Africa, Tripoli, Tripolitania and Cyrenaica }\end{array}$ \\
\hline ITALY & Dodecanese, Italian Aegean Islands, Trieste \\
\hline JAPAN & $\begin{array}{l}\text { Chosen, Formosa, Japan (including Formosa and } \\
\text { Japanese leased territories in China), Japan and } \\
\text { Formosa, Japan and Korea, Japanese Islands, Japanese } \\
\text { Oceania, Korea, South Sea Mandate }\end{array}$ \\
\hline MADAGASCAR AND REUNION & Madagascar, Reunion \\
\hline MANCHUKUO AND KWANTUNG & Manchukuo \\
\hline MAURITIUS AND SEYCHELLES & Mauritius, Seychelles \\
\hline NORWAY & Spitzbergen \\
\hline PALESTINE & Palestine and Transjordan, Transjordan \\
\hline PANAMA & Panama (including canal zone), Panama Canal Zone \\
\hline
\end{tabular}




\begin{tabular}{|l|l|}
\hline PHILIPPINES AND GUAM & Philippines, Guam \\
\hline POLAND AND DANZIG & Poland, Danzig \\
\hline PORTUGUESE ASIA & $\begin{array}{l}\text { Goa, Macao, other Portuguese Asia, Portuguese } \\
\text { possessions in the Indian Seas, Portuguese East Indies, } \\
\text { Portuguese India, Portuguese possessions in the } \\
\text { Orient, Portuguese Timor }\end{array}$ \\
\hline PORTUGAL & $\begin{array}{l}\text { Cape Verde, Mozambique, other Portuguese Africa, } \\
\text { Portuguese East Africa, Portuguese Guinea, } \\
\text { Portuguese West Africa, Sao Thomé, Sao Thomé et } \\
\text { Principe }\end{array}$ \\
\hline PORTUGUESE AFRICA & American Oceania, American Samoa \\
\hline SAMOA & $\begin{array}{l}\text { Basutoland, Bechunnaland Protectorate, } \\
\text { Bechunnaland Protectorate Basutoland and Swaziland, } \\
\text { Swaziland }\end{array}$ \\
\hline SOUTH AFRICA & Canaries, Ceuta, Melilla \\
\hline SPAIN & $\begin{array}{l}\text { Spanish Fez, Spanish Morocco, Spanish Morocco and } \\
\text { Canary Islands }\end{array}$ \\
\hline SPANISH NORTH AFRICA & $\begin{array}{l}\text { Rio de Oro, Spanish Guinea, Spanish West Equatorial } \\
\text { Africa }\end{array}$ \\
\hline SPANISH WEST AFRICA & Liechtenstein \\
\hline SWITZERLAND & French Syria, Syria Lebanon \\
\hline SYRIA & Asia Minor \\
\hline TURKEY & $\begin{array}{l}\text { Channel Islands, England, Great Britain, Northern } \\
\text { Ireland }\end{array}$ \\
\hline UNITED KINGDOM & Uruguay, Paraguay \\
\hline URUGUAY AND PARAGUAY & Alaska \\
\hline VNITED STATES OF AMERICA & Venezuela, Guiana \\
\hline VENEZUELA AND GUIANA & $\begin{array}{l}\text { American Antilles, St Croix, US Virgin Islands, US } \\
\text { West Indies }\end{array}$ \\
\hline VIRGIN ISLANDS & Yugoslavia, Albania \\
\hline YUGOSLAVIA AND ALBANIA &
\end{tabular}

